\title{
¿Solar Radiation in the Arctic during the Early Twentieth-Century Warming (1921-50): Presenting a Compilation of Newly Available Data ${ }^{\mathscr{O}}$
}

\author{
R. PRZYBYLAK \\ Faculty of Earth Sciences and Spatial Management, Department of Meteorology and Climatology, and Centre for Climate Change \\ Research, Nicolaus Copernicus University, Toruń, Poland

\section{P. N. SVYASHCHENNIKOV} \\ Climatology and Environmental Monitoring Department, and Arctic and Antarctic Research Institute, Saint Petersburg State \\ University, Saint Petersburg, Russia \\ J. USCKA-KOWALKOWSKA \\ Faculty of Earth Sciences and Spatial Management, Department of Meteorology and Climatology, Nicolaus Copernicus University, \\ Torun, Poland

\section{P. WYSZYŃSKI} \\ Faculty of Earth Sciences and Spatial Management, Department of Meteorology and Climatology, and Centre for Climate Change \\ Research, Nicolaus Copernicus University, Toruń, Poland
}

(Manuscript received 14 April 2020, in final form 13 July 2020)

\begin{abstract}
The early twentieth-century warming (ETCW), defined as occurring within the period 1921-50, saw a clear increase in actinometric observations in the Arctic. Nevertheless, information on radiation balance and its components at that time is still very limited in availability, and therefore large discrepancies exist among estimates of total solar irradiance forcing. To eliminate these uncertainties, all available solar radiation data for the Arctic need to be collected and processed. Better knowledge about incoming solar radiation (direct, diffuse, and global) should allow for more reliable estimation of the magnitude of total solar irradiance forcing, which can help, in turn, to more precisely and correctly explain the reasons for the ETCW in the Arctic. The paper summarizes our research into the availability of solar radiation data for the Arctic. An important part of this work is its detailed inventory of data series (including metadata) for the period before the midtwentieth century. Based on the most reliable data series, general solar conditions in the Arctic during the ETCW are described. The character of solar radiation changes between the ETCW and present times, in particular after 2000, is also analyzed. Average annual global solar radiation in the Russian Arctic during the ETCW was slightly greater than in the period 1964-90 (by about $1-2 \mathrm{~W} \cdot \mathrm{m}^{-2}$ ) and was markedly greater than in the period 2001-19 (by about $16 \mathrm{~W} \cdot \mathrm{m}^{-2}$ ). Our results also reveal that in the period 1920-2019 three phases of solar radiation changes can be distinguished: a brightening phase (1921-50), a stabilization phase (1951-93), and a dimming phase (after 2000).
\end{abstract}

KEYWORDS: Arctic; Shortwave radiation; Surface observations; Climate variability; Interannual variability; History

\section{Introduction}

Przybylak (2016), in his review of the state of the knowledge concerning solar radiation in the Arctic up to about 2015, concludes that, although there exist a very large number of literature items presenting many aspects of the solar radiation regime (including the radiation balance and its components) in

\footnotetext{
๑ Denotes content that is immediately available upon publication as open access.
}

Supplemental information related to this paper is available at the Journals Online website: https://doi.org/10.1175/JCLI-D-200257.s1.

Corresponding author: Przemysław Wyszyński, przemyslaw. wyszynski@umk.pl the Arctic, the available knowledge about it is still limited, as is evidently seen in the period before 1950. According to that monograph there are two main reasons for this fact: (i) the sparse network of actinometric stations in the Arctic and (ii) the irregularity and rarity of measurements. Besides Przybylak's (2016) review, very good reviews of the state of the radiation measurements in the Arctic were also presented earlier by Gavrilova (1963), Marshunova and Chernigovskiy (1971), Ohmura (1981, 1982), and Stanhill (1995). Przybylak (2003, 2016), carefully analyzing the history of the actinometric measurements in the Arctic (the southern boundary of which was taken after Atlas Arktiki; see Treshnikov 1985), has distinguished five clear periods (phases). The early twentiethcentury warming period (ETCW) covers two of them, that is, the second part of phase 2 [the end of the nineteenth centurythe second International Polar Year (IPY, 1932/33)], and all of phase 3 (the second IPY-1950). Before the 1920s, actinometric measurements were very seldom taken in the Arctic 
(Gavrilova 1963; Przybylak 2003, 2016). A markedly greater number of measurements was noted in the 1920s and in particular at the beginning of the 1930s (e.g., Kalitin 1921, 1924, 1929; Berezkin 1929; Samoilenko 1929; Götz 1931; Mosby 1932; Ångström 1933; Georgi 1935; Olsson 1936a,b; Kopp 1939; Wegener 1939). All these actinometric measurements were, however, of a temporary and episodic character. Later on, beginning with the years 1932-33 (second IPY), actinometric observations were made simultaneously at a number of stations for the first time (Chernigovskiy 1961a,b, hereinafter CH61a, CH61b). Shortly after the end of the second IPY, work began on setting up an actinometric network, and continuous observations began, but only in the Soviet Arctic (six stations) (Przybylak 2016). Thus, continuous actinometric observations by a thermoelectric pyranometer began there only about 10-20 years later than elsewhere in the world (for details see Ohmura 2009; Stanhill and Achiman 2017). Outside the Soviet (now Russian) Arctic, regular observations started in 1950-51 or later (e.g., Gavrilova 1963; Marshunova and Chernigovskiy 1971; Stanhill 1995, see his Table 1; Dissing and Wendler 1998, see their Table 1). We must conclude that there is only very limited knowledge about available solar data for this region of the world and time period. It is sufficient to mention here the recently published review by Stanhill and Achiman (2017) summarizing early global radiation measurements. That paper contains only two sentences very roughly describing knowledge about solar measurements in the Arctic before the 1950s:

In Russia the Pavlovsk series of measurements began in 1912 and was supplemented by a nationwide network of ten stations in the 1920s, 10 years later this was supplemented with six stations in the Arctic using the Yanishevskiy pyranometer throughout the network. Measurements stopped during the Second World War, the network was re-established and expanded in 1946 and by 1960 included more than ten measurement sites north of $65^{\circ}$.

Based on this short review, it can be concluded that the ETCW includes a time when there was a clear increase in actinometric observations in the Arctic. However, access to the measured solar radiation data (published mainly in Russian sources) - and even information about them-is still limited. Although data rescue activity has been growing rapidly around the world in recent decades, it is mainly limited to main meteorological variables such as air temperature, precipitation, and atmospheric pressure (see Brönnimann et al. 2018, 2019). Only quite recently has radiation gained greater attention due to identified periods of "global dimming" and "global brightening" (Wild 2012). However, up until now no one undertook data rescue for solar radiation in the Arctic. As a result, knowledge about Arctic energy balance for the ETCW is still deeply unsatisfactory, and therefore, also, total solar irradiance (TSI) forcing cannot reliably be determined (Bengtsson et al. 2004; Suo et al. 2013). It is sufficient to say that reconstructions in the increase in TSI during the ETCW range from $0.6 \mathrm{~W} \cdot \mathrm{m}^{-2}$ (CMIP5; Wang et al. 2005), through $1.8 \mathrm{~W} \cdot \mathrm{m}^{-2}$ (Crowley et al. 2003), to $3.6 \mathrm{~W} \cdot \mathrm{m}^{-2}$ (Shapiro et al. 2011). Recent results presenting revised historical TSI forcing (Egorova et al. 2018) estimated this change to about $1.2-2.5 \mathrm{~W} \cdot \mathrm{m}^{-2}$ (see their Fig. 8a) using a code for the high spectral resolution reconstruction of solar irradiance (CHRONOS) model. Suo et al. (2013) concluded that the collection and processing of solar data is of paramount and central importance to the ability to take TSI forcing into account, especially in modeling work. Without reliable solar data, the causes of the ETCW in the Arctic are also very difficult to explain. All the aforementioned weaknesses in solar climate knowledge for the Arctic motivated us to include this issue within the research tasks of our project called "Causes of the early 20th century Arctic warming."

The main aim of the present paper is to present (i) a comprehensive review of available actinometric data (including inventory) for the ETCW (1921-50) and earlier; (ii) a preliminary analysis of general solar conditions occurring in this time in terms of global, diffuse, and direct solar radiation; and (iii) an estimation of changes in solar radiation conditions in the Arctic between the ETCW and present times, in particular, after 2000 .

\section{Area, data, and methods}

To reliably highlight the solar radiation conditions during the ETCW, which was defined for the present paper as the period 1921-50, it was first necessary to make an inventory of all series of solar radiation measurements made in the Arctic, and then also to collect all the most valuable data series. For the purpose of the present paper, the Arctic was defined here after Atlas Arktiki (Treshnikov 1985). The results of our library and archival research effort, which was mainly carried out in Russia, the United Kingdom, Canada, and Norway, are summarized in brief in Table 1. Table S1 in the online supplemental material lists short-term series of solar radiation measurements made during expeditions in the Arctic. We decided also to add information about solar radiation observations made in the pre-ETCW period, which are very rare (only four series). Table S2 in the online supplemental material presents separately an inventory of all solar measurements conducted regularly at permanent meteorological stations in the Russian Arctic. All useful metadata in both kinds of inventories is also given (name of station or area, observation period, type and resolution of solar radiation measurements, instruments used, source of data or metadata, etc.). The locations of all areas or sites of actinometric observations during the ETCW are shown in Fig. 1.

For the characteristic of solar radiation conditions during the ETCW some examples of data taken from actinometric stations, having longer series of observations (at least three years) and being more reliable than those made during shortterm expeditions, have been utilized. Global solar radiation and its components (diffuse and direct radiation) have been used for the analysis.

As a rule in the Russian Arctic, direct solar radiation observations were made using the Savinov-Yanishevskiy thermoelectric actinometer, the Michelson actinometer and the Ångström compensation pyrheliometer (see also supplemental Table S1). Global and diffuse solar radiation were measured with a Yanishevskiy pyranometer. Observations using a single methodology were facilitated by the publication of a special guide to actinometric observations in the Arctic (Berezkin 
1937, 1938). The names of actinometric instruments used in other parts of the Arctic are listed in Table S1.

Monthly totals of solar radiation (direct, diffuse, and global) for the period 1934-50 were digitized from CH61a and CH61b. In the mentioned publications all solar data are expressed in calories per centimeter squared per minute in the pyrheliometric Ångström scale, that is, a unit not presently in use. Therefore, for the purposes of comparison with data on contemporary solar conditions, all historical data were recalculated to megajoules per meter squared units in the World Radiometric Reference (WRR) from 1981. For this purpose, coefficients for the pyrheliometric scale suggested by the Russian Federal Service for Hydrometeorology and Environmental Monitoring (Rosgidromet) were utilized (Rosgidromet 1997). All data used in the present paper are available at the repository for open data (http://dx.doi.org/10.18150/repod.0451825; Przybylak et al. 2020). For the present paper they were further recalculated to watts per meter squared, which is the unit now more commonly used by the majority of climatologists. However, we also provide all results expressed in megajoules per meter squared in Figs. S2-S9 in the online supplemental material.

In the original series of solar radiation data, a small number of gaps were identified. Where it was possible, they were filled using the following formula:

$$
I^{\prime}+D=Q
$$

where $I^{\prime}$ is the monthly total of direct solar radiation falling on the horizontal surface, $D$ is the monthly total of diffuse solar radiation, and $Q$ is the monthly total of global solar radiation.

Sokolik (2008) concluded that actinometric stations operated in the Russian Arctic in the period from 1950/60 to 1993, but this conclusion is not fully precise. We have shown that some of the stations began work in the 1930s. Moreover, although Sokolik (2008) was correct that measurements in the Russian Arctic were abandoned in 1993, she did not mention that the break in observations lasted slightly less than 10 years, because some actinometric observations were resumed there after 2000. According to Radionov et al. (2017), actinometric stations in the Russian Arctic were reestablished in Ostrov Vrangelya, Ostrov Dikson, and Mys Chelyuskin in 2001 and in two other stations (Ostrov Vize and Ostrov Golomyannyi) in 2002. Later on, observations started in Uelen in 2004 and in August 2010 in Bukhta Tiksi, but at a new location about $7 \mathrm{~km}$ from where the station had operated during the ETCW period. Presently, however, regular observations are only conducted at three stations (Ostrov Vize, Ostrov Dikson, and Mys Chelyuskin) (V. F. Radionov 2020, personal communication), in contrast to pre-1993, when there were 15 stations operating. Moreover, at present, actinometric observations are not conducted during the polar night (for details see Table 1 in Radionov et al. 2017).

Only two sites (Ostrov Dikson and Mys Chelyuskin belonging to the Russian network of actinometric stations) have solar radiation data for both the ETCW (1937-50) and contemporary (2001-19) periods that is available for comparison. The best data in terms of completeness and duration for both periods exist for Ostrov Dikson. However, it is surprising that for the ETCW there are no gaps in all types of solar radiation data, while for the contemporary period there is quite large number of them. Usually, in the later period, for most months there are at least 15 years with data. However, complete yearly series are available only for 10-12 years, depending on the type of radiation. Data availability for Mys Chelyuskin is, in contrast to Ostrov Dikson, significantly worse for the ETCW than for the contemporary period. For the earlier period data are available for only three years (1937, 1941, and 1950), and, furthermore, they are incomplete, while for the later period data for 19 years exist, but complete yearly series exist for only 4-5 years. Better completeness of data exists for global and direct types of solar radiation than for diffuse radiation. For example, monthly totals are usually available for at least 15 years for the first two solar radiation types but for at least 12 years for diffuse radiation.

\section{Results and discussion}

\section{a. Solar radiation conditions during the ETCW}

Table 1 and Tables S1 and S2 in the online supplemental material together present an inventory of all series of solar radiation measurements in the Arctic prior to the midtwentieth century, which we identified based on available literature. As can be seen, before the ETCW, only four such series exist. The first measurements of solar radiation intensity using black-and-white thermometers were conducted during the second expedition to the Polar Sea in the years 1825, 1826, and 1827, commanded by John Franklin (Franklin 1828). By contrast, the first instrumental measurements in the Arctic were done using an Ångström pyrheliometer in northern Spitsbergen (Treurenberg Bay) in the years 1899-1900 (for more details see Westman 1903). For the period 1921-50 we found information about 27 short-term series of solar radiation measurements conducted during 21 polar expeditions to the Arctic (Table 1, Fig. 1). The majority of them allow for a rough description of solar conditions in Greenland (seven series), Svalbard (six series), and the area of Chukchi Sea and Wrangel Island (five series). Three series exist also for Novaya Zemlya and its surroundings, and also three for the Canadian Arctic. More or less long-term series of solar radiation observations were conducted in the Russian Arctic only after the second IPY 1932/33. As results from Table 1 and supplemental Table S2, we identified 10 actinometric stations for which data exist in the study period. It is also easy to note that there are many gaps in the monthly data.

To roughly describe solar radiation changes in the yearly cycle and to estimate their spatial differences in the area of the Arctic, only data from actinometric stations having at least three years of observations have been used. This criterion was met by seven stations, except for direct solar radiation, for which data from six stations are available. All are located in the Russian Arctic. The data cover the period 1934-50, that is, the second part of the ETCW, though this was the warmer part. Seven stations are shown separately for each kind of solar radiation (direct, diffuse, and global) in Figs. 2-4, respectively, and their locations in Fig. 1. As Fig. 1 shows, stations are roughly evenly distributed across the Russian Arctic and also span eleven degrees of latitude, from $68^{\circ} 55^{\prime} \mathrm{N}$ (Mys Shmidta) to 
TABLE 1. List of sites (or areas) where solar radiation measurements during Arctic expeditions (Nos. 1-32) were taken before the midtwentieth century (including the ETCW period, 1921-50) and actinometric stations (Nos. 33-42) with continuous measurements of solar

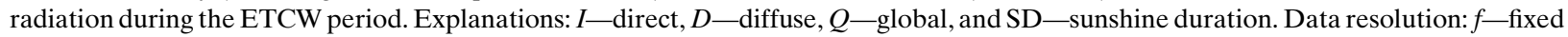
(subdaily data, measurements in only a few selected hours), $h$-hourly, $d$-daily, and $m$-monthly. Other acronyms: AARI—Arctic and Antarctic Research Institute; TM-12-Meteorological Table, type 12 [this table contains measurements of solar radiation (total, diffuse, and direct) for each observation period every day for a month]; TM-13-Meteorological Table, type 13 (this table contains measurements of hourly sums of total solar radiation). All observations are contained in tables, i.e., on paper, and most of them are handwritten.

\begin{tabular}{|c|c|c|c|c|c|}
\hline No. & Site/area & Period & Elements & $\begin{array}{l}\text { Resolution of } \\
\text { available data }\end{array}$ & $\begin{array}{l}\text { Source of data or } \\
\text { metadata }\end{array}$ \\
\hline 1 & Canadian Arctic, Beaufort Sea & $1825-27$ & $\begin{array}{l}\text { Radiation } \\
\text { intensity }\end{array}$ & $f$ & Franklin (1828) \\
\hline 2 & $\begin{array}{l}\text { Polaris Bay }\left(\varphi=81^{\circ} 36^{\prime} \mathrm{N}, \lambda=62^{\circ} 15^{\prime} \mathrm{W}\right) \text {, } \\
\quad \text { East Greenland }\end{array}$ & 4 Mar-21 Jun 1872 & $\begin{array}{l}\text { Radiation } \\
\text { intensity }\end{array}$ & $f$ & Bessels (1876) \\
\hline 3 & $\begin{array}{l}\text { Polaris House }\left(\varphi=78^{\circ} 18^{\prime} \mathrm{N}, \lambda=70^{\circ} 15^{\prime} \mathrm{W}\right) \text {, } \\
\quad \text { East Greenland }\end{array}$ & & & & \\
\hline 4 & $\begin{array}{l}\text { Treurenberg Bay, Spitsbergen } \\
\quad\left(\varphi=79^{\circ} 55^{\prime} 1 \mathrm{~N}, \lambda=16^{\circ} 51^{\prime} 5 \mathrm{E}\right)\end{array}$ & $\begin{array}{l}\text { 5-28 Sep 1899, } 5 \text { Apr-19 } \\
\text { Jul } 1900\end{array}$ & $I$ & $f$ & Westman (1903) \\
\hline 5 & Arkhangelsk, White Sea & 19 Jun-11 Jul 1920 & $I, D$ & $f$ & Kalitin (1921) \\
\hline 6 & Arkhangelsk $\left(\varphi=64^{\circ} 33^{\prime} \mathrm{N}, \lambda=40^{\circ} 32^{\prime} \mathrm{E}\right)$ & 12-20 Aug 1921 & $I, D$ & $f, h, d$ & Kalitin (1924) \\
\hline 7 & $\begin{array}{l}\text { Tchernoy city, Novaya Zemlya } \\
\quad\left(\varphi=70^{\circ} 44^{\prime} \mathrm{N}, \lambda=54^{\circ} 35^{\prime} \mathrm{E}\right)\end{array}$ & 25-27 Aug 1921 & & & \\
\hline 8 & $\begin{array}{l}\text { Karskiye Vorota, Ostrov Vaygatch } \\
\left(\varphi=70^{\circ} 25^{\prime} \mathrm{N}, \lambda=58^{\circ} 40^{\prime} \mathrm{E}\right)\end{array}$ & 29 Aug-24 Sep 1921 & & & \\
\hline 9 & East Siberian Sea, Maud Expedition & $1922-25$ & $Q$ & $f, d$ & Mosby (1932) \\
\hline 10 & $\begin{array}{l}\text { Matochkin Shar, Novaya Zemlya } \\
\quad\left(\varphi=73^{\circ} 15^{\prime} \mathrm{N}, \lambda=56^{\circ} 23^{\prime} \mathrm{E}\right. \\
H=45 \mathrm{~m} \text { MSL })\end{array}$ & $\begin{array}{l}21 \text { Aug-21 Sep } 1923 \\
(Q \text { and } D \text { until } 6 \text { Sep })\end{array}$ & $Q, D, I$ & $f, h$ & Kalitin (1929) \\
\hline 11 & $\begin{array}{l}\text { Steamer Persey, Barents Sea, Novaya } \\
\text { Zemlya, northern part in bays Krestovaya } \\
\text { and Mashiginaya, Gorbovye islands } \\
\text { (around } \varphi=74^{\circ} 10^{\prime} \mathrm{N}, \lambda=55^{\circ} 17^{\prime} \mathrm{E} \text { ) }\end{array}$ & 20 Aug-7 Sep 1926 & $I$ & $f$ & Samoilenko (1929) \\
\hline 12 & $\begin{array}{l}\text { Greenland, trip on inland ice (around } \\
\varphi=66^{\circ} 57^{\prime} \mathrm{N}, \lambda=53^{\circ} 23^{\prime} \mathrm{W} \text { ) }\end{array}$ & 13-20 Aug 1927 & $I$ & $f$ & Kimball (1931) \\
\hline 13 & $\begin{array}{l}\text { Mount Evans, Greenland }\left(\varphi=66^{\circ} 51^{\prime} \mathrm{N}\right. \\
\left.\lambda=50^{\circ} 50^{\prime} \mathrm{W}, H=374 \mathrm{~m} \text { MSL }\right)\end{array}$ & 6 Sep 1927-17 Apr 1928 & $I$ & $f$ & Kimball (1931) \\
\hline 14 & $\begin{array}{l}\text { Green Harbour, Spitzbergen, } \varphi=78^{\circ} 00^{\prime} \mathrm{N} \\
\quad \lambda=14^{\circ} 05^{\prime} \mathrm{E}\end{array}$ & 4 Sep 1927-6 Aug 1928 & $Q, I$ & $f, d$ & Kimball (1931) \\
\hline 15 & $\begin{array}{c}\text { Chukchi Sea (11 series), area: } 70^{\circ} 37^{\prime} \mathrm{N}- \\
71^{\circ} 21^{\prime} \mathrm{N} \text { and } 168^{\circ} 31^{\prime} \mathrm{E}-174^{\circ} 48^{\prime} \mathrm{E}\end{array}$ & 13 Aug-3 Sep 1929 & $Q, D$ & $f, d$ & Berezkin (1929) \\
\hline 16 & $\begin{array}{l}\text { Wrangel Island }\left(\varphi=71^{\circ} 14^{\prime} \mathrm{N}\right. \\
\left.\lambda=179^{\circ} 25^{\prime} \mathrm{W}\right), \text { coast of Rogers Bay }(5 \\
\text { series })\end{array}$ & 13 Aug-3 Sep 1929 & & & \\
\hline 17 & $\begin{array}{l}\text { Chukotka Peninsula, Bay Provedeniya } \\
\left(\varphi=64^{\circ} 25^{\prime} \mathrm{N}, \lambda=173^{\circ} 15^{\prime} \mathrm{W}\right)\end{array}$ & 16 Sep 1929 & & & \\
\hline 18 & $\begin{array}{l}\text { Kings Bay, Spitsbergen }\left(\varphi=78^{\circ} 55^{\prime} \mathrm{N}\right. \\
\left.\lambda=11^{\circ} 56^{\prime} \mathrm{E}\right)\end{array}$ & 1929 & $I ?$ & $f ?$ & Götz (1931) \\
\hline 19 & $\begin{array}{l}\text { West Greenland (West Station and Umanak } \\
\left.\text { Station, } \varphi=70^{\circ} 40^{\prime} \mathrm{N}, \lambda=52^{\circ} 07^{\prime} \mathrm{W}\right)\end{array}$ & 1929 and $1930-31$ & $Q, I$ & $h$ & $\begin{array}{r}\text { Georgi (1935); } \\
\text { Kopp (1939) }\end{array}$ \\
\hline 20 & $\begin{array}{l}\text { Central Greenland (Eismitte Station, } \\
\left.\varphi=71^{\circ} 10^{\prime} \mathrm{N}, \lambda=39^{\circ} 56^{\prime} \mathrm{W}\right)\end{array}$ & & & & \\
\hline 21 & $\begin{array}{l}\text { East Greenland (East Station in } \\
\left.\quad \text { Scoresbysund, } \varphi=70^{\circ} 29^{\prime} \mathrm{N}, \lambda=23^{\circ} 21^{\prime} \mathrm{W}\right)\end{array}$ & $\begin{array}{l}5 \text { Aug-27 Oct } 1930 \text { and } \\
25 \text { Feb-6 Aug } 1931\end{array}$ & & & \\
\hline 22 & $\begin{array}{l}\text { Sveanor, Spitsbergen }\left(\varphi=79^{\circ} 56^{\prime} 5 \mathrm{~N}\right. \\
\left.\quad \lambda=18^{\circ} 18^{\prime} \mathrm{E}\right)\end{array}$ & 2 Jul-10 Aug 1931 & $Q$ & $h, d$ & Ångström (1933) \\
\hline 23 & Coppermine $\left(\varphi=67^{\circ} 49^{\prime} \mathrm{N}, \lambda=115^{\circ} 05^{\prime} \mathrm{W}\right)$ & $\begin{array}{l}1 \text { Sep-20 Nov } 1932, \\
15 \text { Jan-25 Aug } 1933\end{array}$ & $Q, \mathrm{SD}$ & $d(Q), h(\mathrm{SD})$ & $\begin{array}{l}\text { Meteorological Services } \\
\text { of Canada (1940) }\end{array}$ \\
\hline 24 & $\begin{array}{l}\text { Chesterfield Inlet }\left(\varphi=63^{\circ} 20^{\prime} \mathrm{N}\right. \\
\left.\quad \lambda=90^{\circ} 42^{\prime} \mathrm{W}\right)\end{array}$ & $\begin{array}{c}Q \text { (1 Sep 1932-31 Aug } \\
\text { 1933), SD (20 Aug } \\
\text { 1932-10 Sep 1933) }\end{array}$ & $Q, \mathrm{SD}$ & $d(Q), h(\mathrm{SD})$ & $\begin{array}{l}\text { Meteorological Services } \\
\text { of Canada (1940) }\end{array}$ \\
\hline 25 & $\begin{array}{l}\text { Cape Hope's Advance }\left(\varphi=61^{\circ} 05.2^{\prime} \mathrm{N}\right. \\
\left.\quad \lambda=69^{\circ} 33.4^{\prime} \mathrm{W}\right)\end{array}$ & 3 Aug 1932-30 Sep 1933 & SD & $h$ & $\begin{array}{l}\text { Meteorological Services } \\
\text { of Canada (1940) }\end{array}$ \\
\hline
\end{tabular}


TABLE 1. (Continued)

\begin{tabular}{|c|c|c|c|c|c|}
\hline No. & Site/area & Period & Elements & $\begin{array}{l}\text { Resolution of } \\
\text { available data }\end{array}$ & $\begin{array}{l}\text { Source of data or } \\
\text { metadata }\end{array}$ \\
\hline 26 & $\begin{array}{l}\text { Mount Nordenskiöld, Spitsbergen } \\
\quad\left(\varphi=78^{\circ} 10^{\prime} 8 \mathrm{~N}, \lambda=15^{\circ} 26^{\prime} 4 \mathrm{E}\right. \\
H=1049 \mathrm{~m} \mathrm{MSL})\end{array}$ & 1 Aug 1932-1 Sep 1933 & SD & $h, d$ & Olsson (1936a) \\
\hline 27 & $\begin{array}{l}\text { Isachsen's Plateau, Spitsbergen } \\
\left(\varphi=79^{\circ} 09^{\prime} \mathrm{N}, \lambda=12^{\circ} 56^{\prime} \mathrm{E}\right. \\
H=850 \mathrm{~m} \mathrm{MSL})\end{array}$ & $\begin{array}{l}26 \text { Jun } 1934-15 \\
\text { Aug } 1934\end{array}$ & $Q, D, I, \mathrm{SD}$ & $h, d$ & Olsson (1936b) \\
\hline 28 & Chukchi Sea & August 1935 & $I$ & $f$ & Piotrovitch (1936) \\
\hline 29 & $\begin{array}{l}\text { West Greenland, Sukkertoppen Ice Cap } \\
\qquad\left(\varphi=79^{\circ} 09^{\prime} \mathrm{N}, \lambda=12^{\circ} 56^{\prime} \mathrm{W}\right)\end{array}$ & summer 1938 & $Q$ & $h, d ?$ & $\begin{array}{l}\text { Ruthe (1941); Sugden } \\
\text { and Mott (1940) }\end{array}$ \\
\hline 30 & $\begin{array}{l}\text { Fröya Glacier, Northeast Greenland } \\
\quad\left(\varphi=74^{\circ} 16^{\prime} \mathrm{N}, \lambda=21^{\circ} 00^{\prime} \mathrm{W}\right)\end{array}$ & 31 Jul-18 Aug 1939 & $Q$ & $h, d$ & Eriksson (1942) \\
\hline 31 & $\begin{array}{l}\text { Arctic Ocean near North Pole }\left(\varphi=81^{\circ} 29^{\prime} \mathrm{N}\right. \\
\left.\quad \lambda=179^{\circ} 13^{\prime} \mathrm{E}\right)\end{array}$ & April 1941 & $Q, D$ & $f, h$ & Chernigovskiy (1946) \\
\hline 32 & Wrangel Island & 24 Mar 1941-3 May 1941 & $Q$ & $f, d$ & Chernigovskiy (1948) \\
\hline 33 & $\begin{array}{l}\text { Matochkin Shar }\left(\varphi=73^{\circ} 16^{\prime} \mathrm{N}, \lambda=56^{\circ} 24^{\prime} \mathrm{E}\right. \\
\quad H=18.5 \mathrm{~m} \text { MSL })\end{array}$ & $1931-32$ & $D, Q$ & $f$ & $\begin{array}{l}\text { AARI Table TM-12, } \\
\text { TM-13 }\end{array}$ \\
\hline 34 & $\begin{array}{l}\text { Bukhta Tikhaya }\left(\varphi=80^{\circ} 19^{\prime} \mathrm{N}, \lambda=52^{\circ} 48^{\prime} \mathrm{E} \text {, }\right. \\
\quad H=12 \mathrm{~m} \text { MSL })\end{array}$ & 1933-42 & $I, D, Q$ & $h, f, m$ & $\begin{array}{l}\text { AARI Tables TM-12, } \\
\text { TM-13; } \\
\text { CH61a, CH61b }\end{array}$ \\
\hline 35 & $\begin{array}{l}\text { Ostrov Uedineniya }\left(\varphi=77^{\circ} 30^{\prime} \mathrm{N}\right. \\
\left.\lambda=82^{\circ} 14^{\prime} \mathrm{E}, H=9.7 \mathrm{~m} \mathrm{MSL}\right)\end{array}$ & $1934-50$ & $I, D, Q$ & $h, f, m$ & $\begin{array}{l}\text { AARI Tables TM-12, } \\
\text { 13-TM; } \\
\text { CH61a, CH61b }\end{array}$ \\
\hline 36 & $\begin{array}{l}\text { Bukhta Tiksi }\left(\varphi=71^{\circ} 35^{\prime} \mathrm{N}, \lambda=128^{\circ} 55^{\prime} \mathrm{E}\right. \\
\quad H=6 \mathrm{~m} \text { MSL })\end{array}$ & 1935-41 & $I, D, Q$ & $h, f, m$ & $\begin{array}{l}\text { AARI Tables TM-12, } \\
\text { TM-13; } \\
\text { CH61a, CH61b }\end{array}$ \\
\hline 37 & $\begin{array}{l}\text { Mys Shmidta }\left(\varphi=68^{\circ} 55^{\prime} \mathrm{N}, \lambda=179^{\circ} 25^{\prime} \mathrm{W}\right. \\
\quad H=6,5 \mathrm{~m} \text { MSL })\end{array}$ & $1935-50$ & $I, D, Q$ & $h, f, m$ & $\begin{array}{l}\text { AARI Tables TM-12, } \\
\text { TM-13, } \\
\text { CH61a, CH61b }\end{array}$ \\
\hline 38 & $\begin{array}{l}\text { Mys Chelyuskin }\left(\varphi=77^{\circ} 43^{\prime} \mathrm{N}, \lambda=104^{\circ} 17^{\prime} \mathrm{E}\right. \\
\quad H=16 \mathrm{~m} \text { MSL })\end{array}$ & $1936-50$ & $I, D, Q$ & $h, f, m$ & $\begin{array}{l}\text { AARI Table TM-12, } \\
\text { TM-13; } \\
\text { CH61a, CH61b }\end{array}$ \\
\hline 39 & $\begin{array}{l}\text { Mys Zhelaniya }\left(\varphi=76^{\circ} 56^{\prime} \mathrm{N}, \lambda=68^{\circ} 58^{\prime} \mathrm{E}\right. \\
\quad H=7.5 \mathrm{~m} \text { MSL })\end{array}$ & 1937 & $D, Q$ & $m$ & CH61b \\
\hline 40 & $\begin{array}{l}\text { Ostrov Dikson }\left(\varphi=73^{\circ} 30^{\prime} \mathrm{N}, \lambda=80^{\circ} 24^{\prime} \mathrm{E}\right. \\
\quad H=20 \mathrm{~m} \text { MSL })\end{array}$ & $1937-50$ & $I, D, Q$ & $h, f, m$ & $\begin{array}{l}\text { AARI Tables TM-12, } \\
\text { TM-13; } \\
\text { CH61a, CH61b }\end{array}$ \\
\hline 41 & $\begin{array}{l}\text { Ostrov Moustakh }\left(\varphi=71^{\circ} 33^{\prime} \mathrm{N}\right. \\
\left.\quad \lambda=130^{\circ} 02^{\prime} \mathrm{E}, H=1 \mathrm{~m} \mathrm{MSL}\right)\end{array}$ & $1945-50$ & $I, Q$ & $h, f, m$ & $\begin{array}{l}\text { AARI Tables TM-12, } \\
\text { TM-13; } \\
\text { CH61a, CH61b }\end{array}$ \\
\hline 42 & $\begin{array}{l}\text { Ostrov Rudolfa }\left(\varphi=81^{\circ} 48^{\prime} \mathrm{N}, \lambda=58^{\circ} 00^{\prime} \mathrm{E}\right. \\
H=47 \mathrm{~m} \mathrm{MSL})\end{array}$ & 1949-50 & $I, D, Q$ & $f$ & $\begin{array}{l}\text { AARI Tables TM-12, } \\
\text { TM-13 }\end{array}$ \\
\hline
\end{tabular}

$80^{\circ} 19^{\prime} \mathrm{N}$ (Bukhta Tikhaya). All stations lie near the coast at altitudes no higher than $20 \mathrm{~m}$ MSL.

\section{1) DIRECT RADIATION}

In the annual cycle markedly larger monthly average values of direct solar radiation calculated at the horizontal surface are measured for April-July than for the rest of the year (Fig. 2). Monthly averages were greatest in either June or July. Cloudiness is the most important driver of this pattern.

In northern stations (above $73^{\circ} \mathrm{N}$ ) the largest monthly averages of direct solar radiation reached about $60-70 \mathrm{~W} \cdot \mathrm{m}^{-2}$, and almost $95 \mathrm{~W} \cdot \mathrm{m}^{-2}$ in southern ones. There are two main reasons for these very large differences, which are also noted in other analyzed months: (i) geographical latitude as a dominant factor and (ii) concentration of aerosols, which during the
ETCW was probably significantly greater in the west part of the Russian Arctic (all three northern stations are located here) than in its eastern part. In the 1930s, a large sulfate concentration was found in Spitsbergen (Lomonosovfonna ice core analysis), which was the greatest in the entire twentieth century [see Fig. 8 in Kekonen (2006) or Fig. 4 in Grant et al. (2009)]. According to Hegerl et al. (2018), the many large spikes noted in this time were a consequence of enlarged transport of polluted air from central and western Europe toward the Arctic. They also documented that this transport was possible due to changes in atmospheric circulation that they had identified, which led to southerly flow into the Arctic. More recently this change in circulation in the western Arctic (the Norwegian and Barents Seas) during the 1930s was confirmed also by Svyashchennikov et al. (2020, see their Fig. 2). 

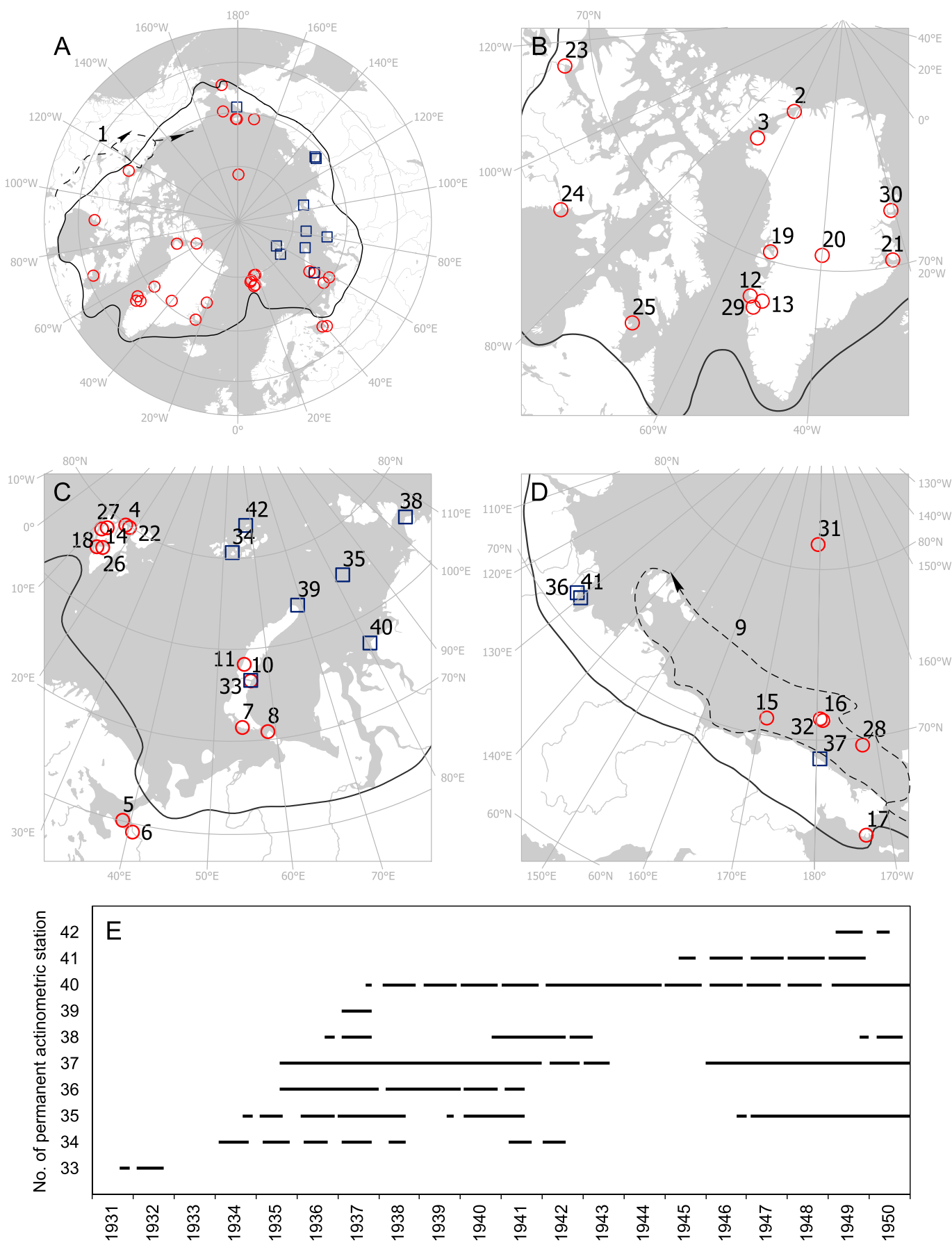

FIG. 1. Location of solar radiation measurement sites/areas in (a) the whole Arctic; (b) the Canadian, Baffin Bay, and Greenland regions; (c) the Atlantic region; and (d) the Siberian region for the period before the mid-twentieth century (including the ETCW, 1921-50). The black solid line in (a)-(d) shows the boundary of the Arctic according to Atlas Arktiki (Treshnikov 1985). (e) Temporal distribution of measurements in the permanent actinometric stations. Available series of measurements taken during expeditions are shown with red circles or dashed lines: 1) Franklin's Arctic route in 1825-27, 2) Polaris Bay, 3) Polaris House, 4) Treurenberg Bay, 5) Arkhangelsk/White Sea, 6) Arkhangelsk, 7) Tchernoy city, 8) Ostrov Vaygatch, 9) Maud's route in 1922-25, 10) Matochkin Shar, 11) Steamer Persey, 12) University of Michigan Expedition, 13) Mount Evans, 14) Green Harbor, 15) Chukchi Sea, 16) Wrangel Island, 17) Bukhta Provideniya, 18) Kings Bay, 19) Uummannaq (Umanak), 20) Eismitte, 21) East Station, 22) Sveanor, 23) Coppermine, 24) Chesterfield Inlet, 25) Cape Hope's Advance, 26) Mount Nordenskiöld, 27) Isachsen's Plateau, 28) Chukchi Sea, 29) Sukkertoppen Ice Cap, 30) Fröya Glacier, 31) expedition by airplane USSR-N-169, and 32) Wrangel Island. Available series of measurements conducted in the permanent actinometric stations are shown with blue squares: 33) Matochkin Shar, 34) Bukhta Tikhaya, 35) Ostrov Uedineniya, 36) Bukhta Tiksi, 37) Mys Shmidta, 38) Mys Chelyuskin, 39) Mys Zhelaniya, 40) Ostrov Dikson, 41) Ostrov Moustakh, and 42) Ostrov Rudolfa. Chronological order is used in numbering sites/areas for both categories of data. For more details, see Table 1 along with Tables S1 and S2 in the online supplemental material. 

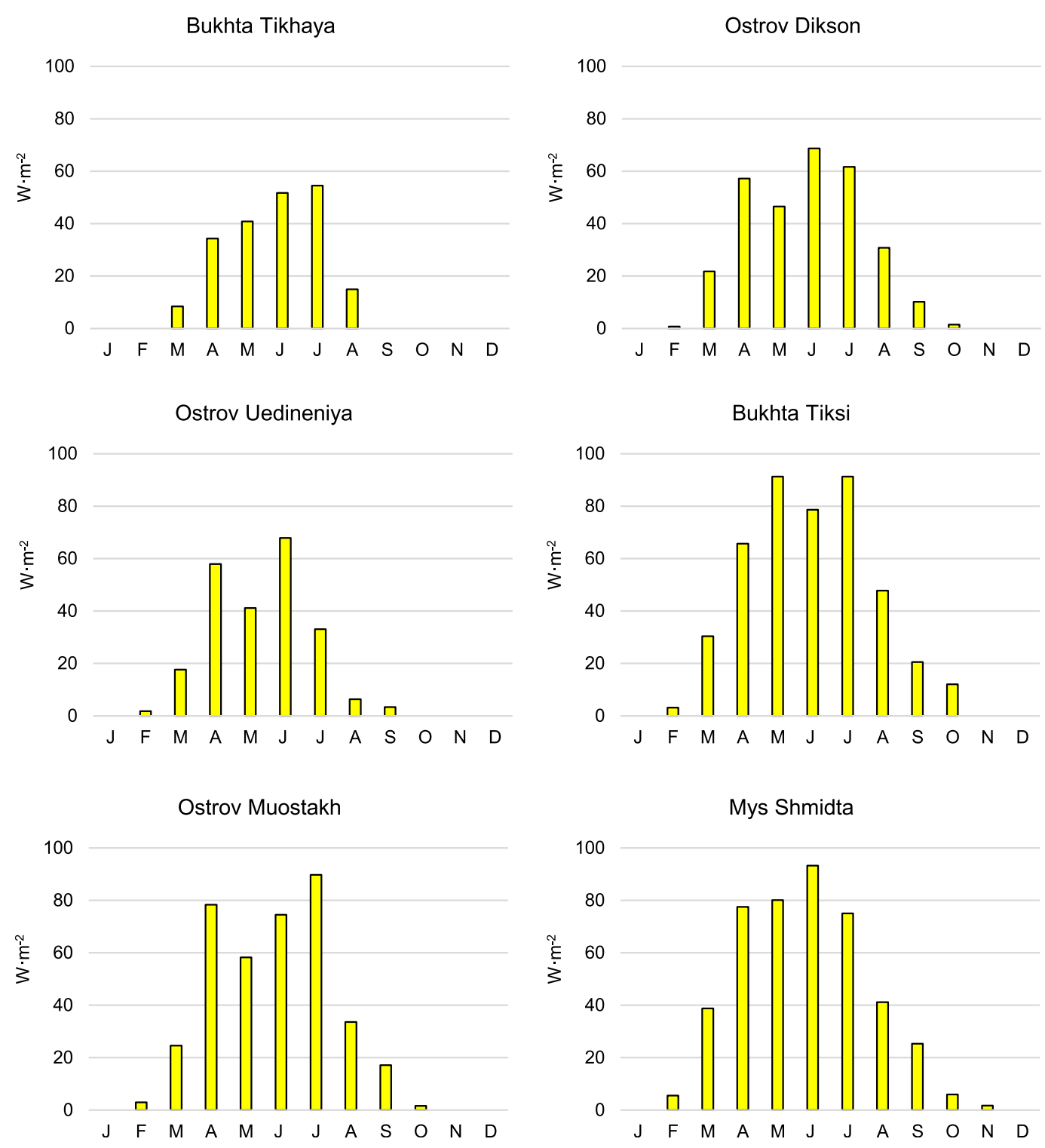

FIG. 2. Monthly average values of direct solar radiation in the Russian Arctic during the ETCW.

Recent results presented by Rusina et al. (2013) and Radionov et al. (2017) concerning analysis of changes in atmospheric optical depth (AOD) in the Russian Arctic after 2000 evidently confirmed the existence of greater values in the western part than in the eastern part. The third possible reason for the described differences in direct solar radiation in the Russian Arctic, that is, spatial changes in cloudiness, is according to us, of less importance; nevertheless, it too could have influenced the spatial radiation pattern due to the fact that cloudiness is usually slightly smaller and low clouds usually fewer in the east of the Russian Arctic than in its western part (e.g., Radionov 1997; Przybylak 2016, see his Figs. 5.1 and 5.2; Chernokulsky and Esau 2019).

Annual averages show 1.5-2.0 times as much direct radiation in the east of the Russian Arctic, where it varied from about 30 to $37 \mathrm{~W} \cdot \mathrm{m}^{-2}$, as in the west (in most northern sites less than $20 \mathrm{~W} \cdot \mathrm{m}^{-2}$ ). The large pollution occurring in the Arctic in the 1930s may be in contrast to the greatest observed warming being in this decade. It is, however, probable that the enlarged advection of warm air from the south connected with atmospheric circulation changes, described above after Hegerl et al. (2018), was greater than the loss of energy associated with the decrease in downward shortwave solar radiation. What is more, Hegerl et al. (2018) argue that aerosols on snow may have strengthened the extraordinary warming in the Arctic during the 1920s and 1930s.

\section{2) DIFFUSE RADIATION}

The magnitude of diffuse solar radiation anywhere in the world depends on solar elevation, type and amount of cloudiness, 

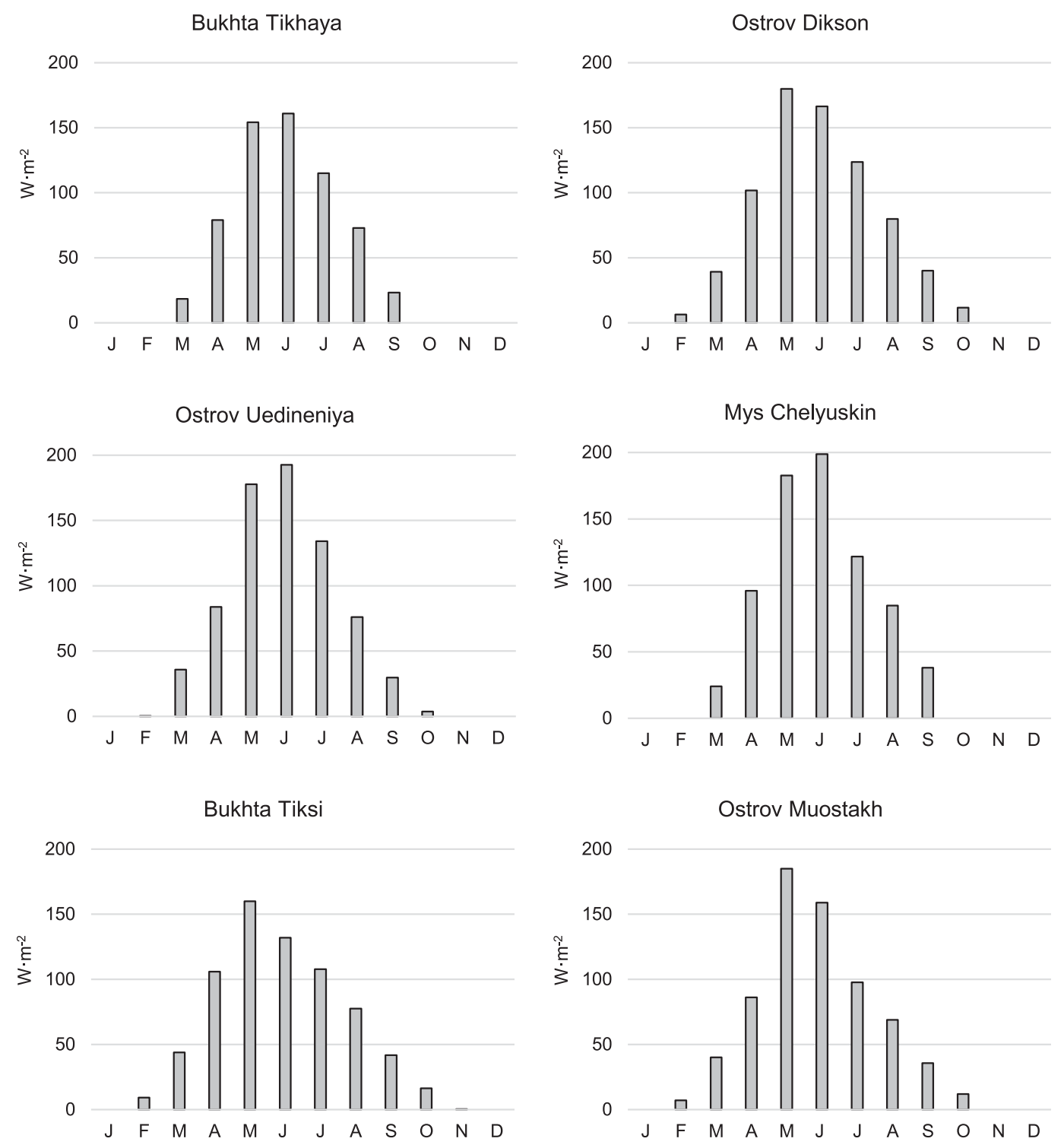

Mys Shmidta

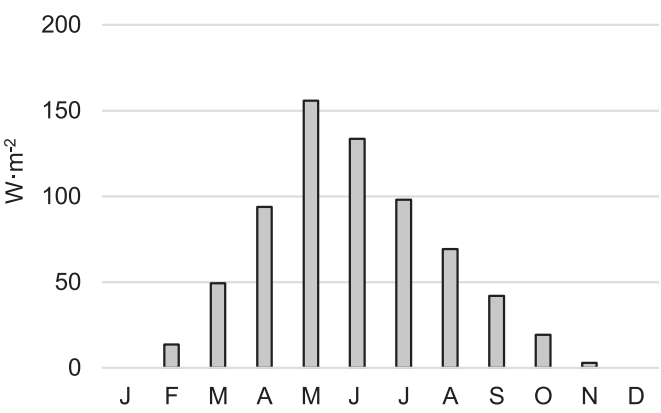

FIG. 3. As in Fig. 2, but for diffuse solar radiation. 

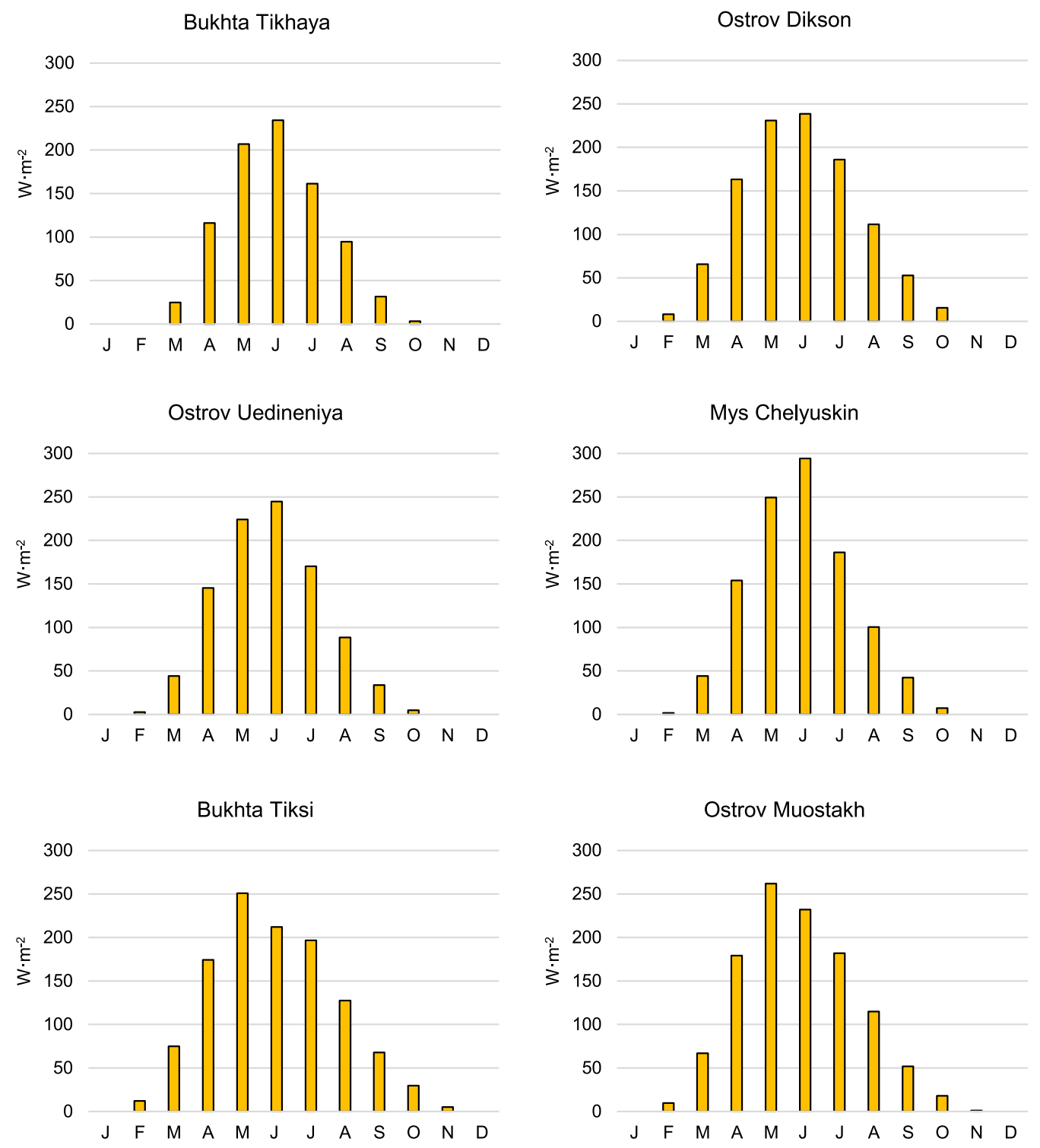

Mys Shmidta

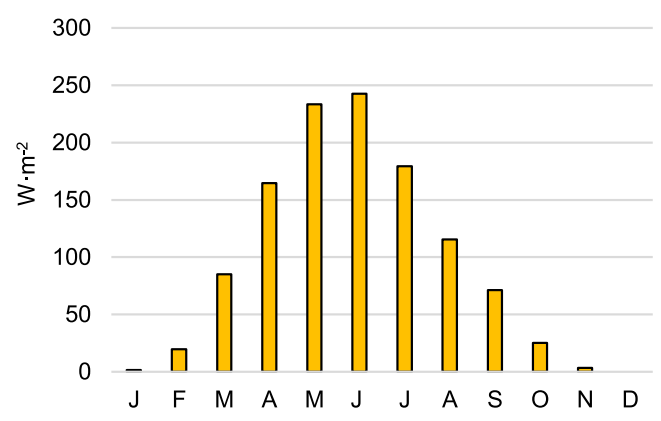

FIG. 4. As in Fig. 2, but for global solar radiation. 
transparency of atmosphere, and surface albedo. In all months and for the year as a whole, diffuse solar radiation in the Russian Arctic in the ETCW was usually about double the direct radiation on a horizontal plane (cf. Figs. 3, 2). Similar results were found by Marshunova and Mishin (1994), when analyzing data of solar radiation based on measurements done in the drifting research stations operating in the Arctic from 1950 to 1991, and also by Radionov (1997).

The clear domination of the diffuse solar radiation component in global radiation results mainly from the fact that, in summer in the Arctic, cloudiness is among the greatest in the world and is furthermore dominated by low and middle clouds (by type, the vast majority are layered clouds) (see Fig. 5.2 in Przybylak 2016), while in spring, large albedo (about $80 \%$ ) is the characteristic feature of the surface [see Fig. 3.4 in Przybylak (2016) and Table 14 in Marshunova and Mishin (1994)]. The greatest diffuse radiation in the annual cycle during the studied part of the ETCW occurred on average either in May or in June (Fig. 3). Their values ranged between $150 \mathrm{~W} \cdot \mathrm{m}^{-2}$ and almost $200 \mathrm{~W} \cdot \mathrm{m}^{-2}$, except for June averages in Bukhta Tiksi and Mys Shmidta (about $130 \mathrm{~W} \cdot \mathrm{m}^{-2}$ ). The lowest annual average diffuse radiation (slightly above $50 \mathrm{~W} \cdot \mathrm{m}^{-2}$ ) were noted in the most northern site (i.e., Bukhta Tikhaya, Franz Joseph Land), which of course is connected mainly with the low solar elevation. The second area where smaller values of diffuse radiation occurred is clearly the east of the Russian Arctic represented by stations Bukhta Tiksi (this station was poorly located and its observations must be analyzed with care), Ostrov Muostakh, and Mys Shmidta (all lying at longitudes east of $120^{\circ} \mathrm{E}$ ). Annual average diffuse solar radiation during the ETCW here ranged around $58 \mathrm{~W} \cdot \mathrm{m}^{-2}$. Meanwhile, the west of the Russian Arctic was characterized by the largest annual average diffuse solar radiation, which varied between 60 and $63 \mathrm{~W} \cdot \mathrm{m}^{-2}$. The described spatial pattern of diffuse radiation in the Russian Arctic seems to be influenced mainly by the amount of sulfate aerosol transported to the western of the Russian Arctic in the 1930s being greater than that transported to its eastern part. The solar elevation played a significantly less important role (stations in the east have lower latitudes than those in the west), except in the most northern part of the study area. This hypothesis is confirmed strongly by Marshunova et al. (1988), who documented that in the period 1940-82 spring values of AOD were 2 times as great in the western Russian Arctic as in its eastern part. In summer, these differences were smaller but also existed.

\section{3) Global RAdiation}

In the annual cycle, global solar radiation in the study area was clearly greatest in May and June (Fig. 4). In May, maximum solar radiation occurred mainly in the eastern part of the Russian Arctic, and in its western part in June. Their values most often ranged around $250 \mathrm{~W} \cdot \mathrm{m}^{-2}$ and rarely approached $300 \mathrm{~W} \cdot \mathrm{m}^{-2}$ (only in Mys Chelyuskin). Large values of global solar radiation occurred also in July (150-200 W.m ${ }^{-2}$ ), April (usually between 115 and $180 \mathrm{~W} \cdot \mathrm{m}^{-2}$ ), and August (85-115 $\mathrm{W} \cdot \mathrm{m}^{-2}$ ). From September to March monthly average values of global solar radiation were usually close to or below $50 \mathrm{~W} \cdot \mathrm{m}^{-2}$, except Mys Shmidta in September-71.2 W.m ${ }^{-2}$ (Fig. 4).
Yearly statistics markedly confirm that during the ETCW the eastern part of the Russian Arctic was more sunny than the western part and received $16-22 \mathrm{~W} \cdot \mathrm{m}^{-2}$ more energy than Bukhta Tikhaya and Ostrov Uedineniya, which are located farthest north (Fig. 4). The spatial pattern of direct solar radiation is mainly responsible for the described features of the global radiation in the Russian Arctic in the study period.

Year-to-year changes in the annual average values of all kinds of solar radiations in the area of the Russian Arctic during the ETCW (but mainly in its latter part) are presented in Figs. 5 and 6. The quite large number of gaps in monthly averages do not allow some yearly averages to be reliably calculated and therefore these years were omitted from the analysis. As results from both figures, the best and most complete data, which are available for the period from 1938 (1939) to 1950, exist for just one station (Ostrov Dikson). All kinds of solar radiation available for this station reveal no trends in the mentioned period. Data from other stations, although irregular, seem also to confirm this conclusion. What is worth noting is the fact that the smallest changes between analyzed stations were observed for diffuse solar radiation, while the greatest were for direct radiation.

Reliable long-term solar radiation data for the Russian Arctic are not available for earlier years of the ETCW. However, for this time, data are available for some European stations, including data since 1922 for Stockholm, Sweden (Ohmura 2009; Wild et al. 2017), which is not far from the Arctic. Thus, it seems to us that it is reasonable to assume that similar changes in solar conditions as in Stockholm could also have occurred in the study area. In Stockholm, annual average global solar radiation shows no important changes until the late 1930s $\left(100-110 \mathrm{~W} \cdot \mathrm{m}^{-2}\right)$ and then there was a rapid increase of about 10-20 W.m ${ }^{-2}$ (Ohmura 2009; Wild et al. 2017). High values of solar radiation were noted from the 1940s until the early 1950s [see Fig. 1 in Ohmura (2009) or Fig. 2 in Wild et al. (2017)]. Such changes in global solar radiation are in good agreement with the abrupt decrease in concentration of sulfate aerosols in Spitsbergen from the level of 800-1000 $\mu \mathrm{g} \cdot \mathrm{L}^{-1}$ in the late 1930 s to $50-200 \mu \mathrm{g} \cdot \mathrm{L}^{-1}$ in the 1940 s (see Fig. 8 in Hegerl et al. 2018), which are the lowest values in the entire twentieth century. The very high atmospheric transparency in this time in the Arctic is also confirmed by the AOD data from Ostrov Dikson, where AOD ranged between 0.07 and 0.10 in the 1940s, and was 1.5-2.0 times smaller than in the years 195180 (Sokolik 2008) and smaller than in the years 2001-11 by a factor of as much as 2-5 (see Fig. 2 in Radionov et al. 2017). A composite of 56 European Global Energy Balance Archive (GEBA) time series encompassing the period 1939-2013 also shows the greatest annual surface downward radiation in 1940 and 1950 (see Fig. 5 in Wild et al. 2017).

\section{b. Comparison with present-day solar conditions}

Starting from the second half of the twentieth century, the availability of solar radiation data both in global and regional (Arctic) terms is evidently greater than for the ETCW period. According to Ohmura (2009), in the global perspective (data from 400 stations) three phases in solar radiation changes can be distinguished: (i) a first brightening phase (from the 1920s to 


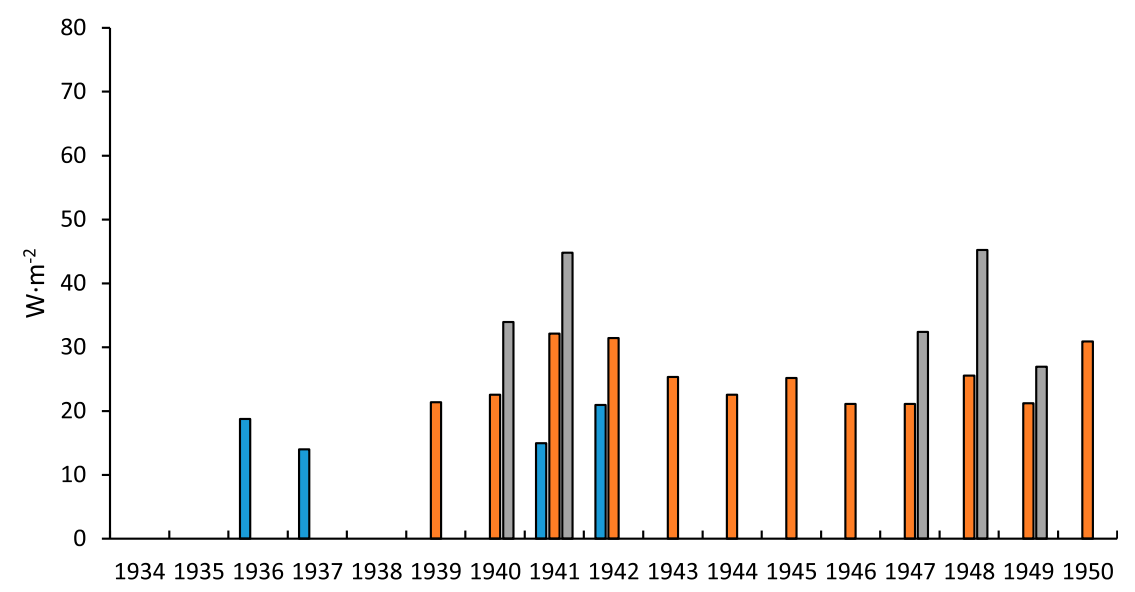

a) $\square$ Bukhta Tikhaya $\quad$ OStrov Dikson $\square$ Mys Shmidta

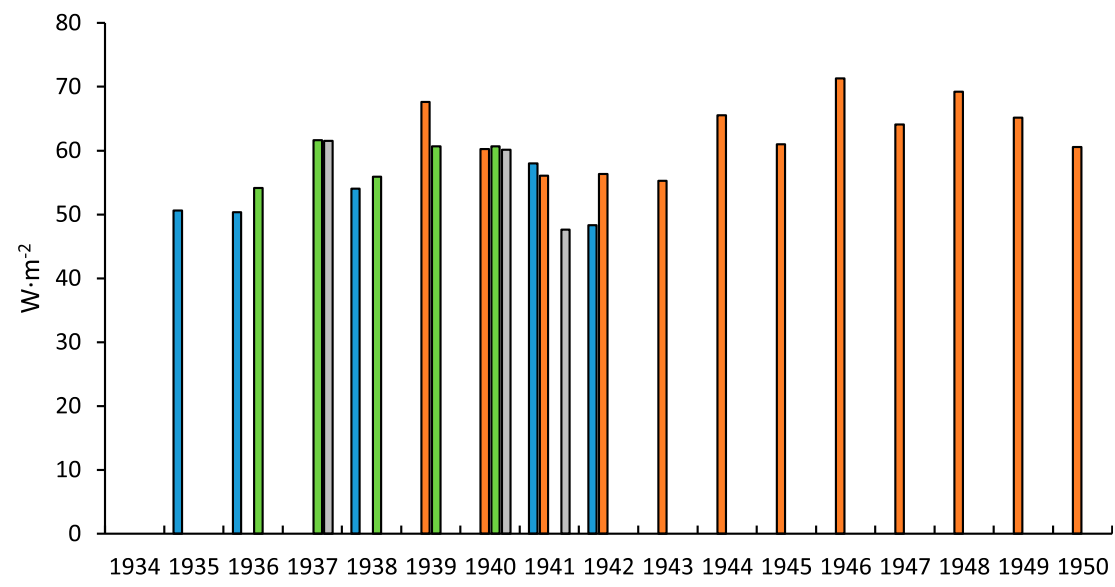

b)

口Bukhta Tikhaya $\quad$ Ostrov Dikson $\quad$ Bukhta Tiksi $\quad$ Mys Shmidta

FIG. 5. Year-to-year courses of annual means of (a) direct and (b) diffuse solar radiation in the Russian Arctic during the ETCW.

the late 1940s/early 1960s), thus encompassing the entire ETCW period; (ii) a dimming phase, with the decreasing trend lasting to the late 1980s; and (iii) a second brightening phase, which was recently documented to have lasted until at least 2010 (Samukova et al. 2014). Samukova et al. (2014) found, analyzing data from 180 European actinometric stations, that the second brightening phase was an effect of a rising tendency in direct solar radiation $\left(8.3 \%\right.$ decade $\left.^{-1}\right)$, because the diffuse radiation in this time decreased at a rate of $3.1 \%$ decade $^{-1}$. According to Ohmura (2009), these decadal changes are mainly the effect of fluctuations both in aerosol and in cloudiness.

Ohmura (2009) argued that such changes in global radiations are noted also in the polar regions, including the Arctic, in the second half of the twentieth century. This conclusion is based on data from only six stations. Unfortunately, their names are not listed in the paper and therefore the locations and number of stations taken from the Arctic are not known. More recently the occurrence of solar dimming and solar brightening in the Russian Arctic was questioned by Radionov et al. (2017). They documented, based on analysis of six stations with long-term series of observations (see their Fig. 3), that in the second half of the twentieth century, stable solar conditions prevailed. Our results, limited to only two stations (Ostrov Dikson and Mys Chelyuskin) with quite long series of observation during the ETCW period, reveal that annual average global solar radiation values in 1964-90 were only slightly smaller (by about $1-2 \mathrm{~W} \cdot \mathrm{m}^{-2}$ ) than during the ETCW. These stable solar conditions in the second half of the twentieth century in the Russian Arctic were noted despite the observed increasing anthropogenic pollution in this time. The reason for this, according to recent analysis of cloud cover fluctuations in the Eurasian Arctic in the period 1936-2012 (Chernokulsky and Esau 2019), is their documented (see Fig. 5) lowest total cloudiness occurring in the period 1970-90, in particular in spring, but also in summer, but mainly in its western part. After 2000 the Russian Arctic saw an 

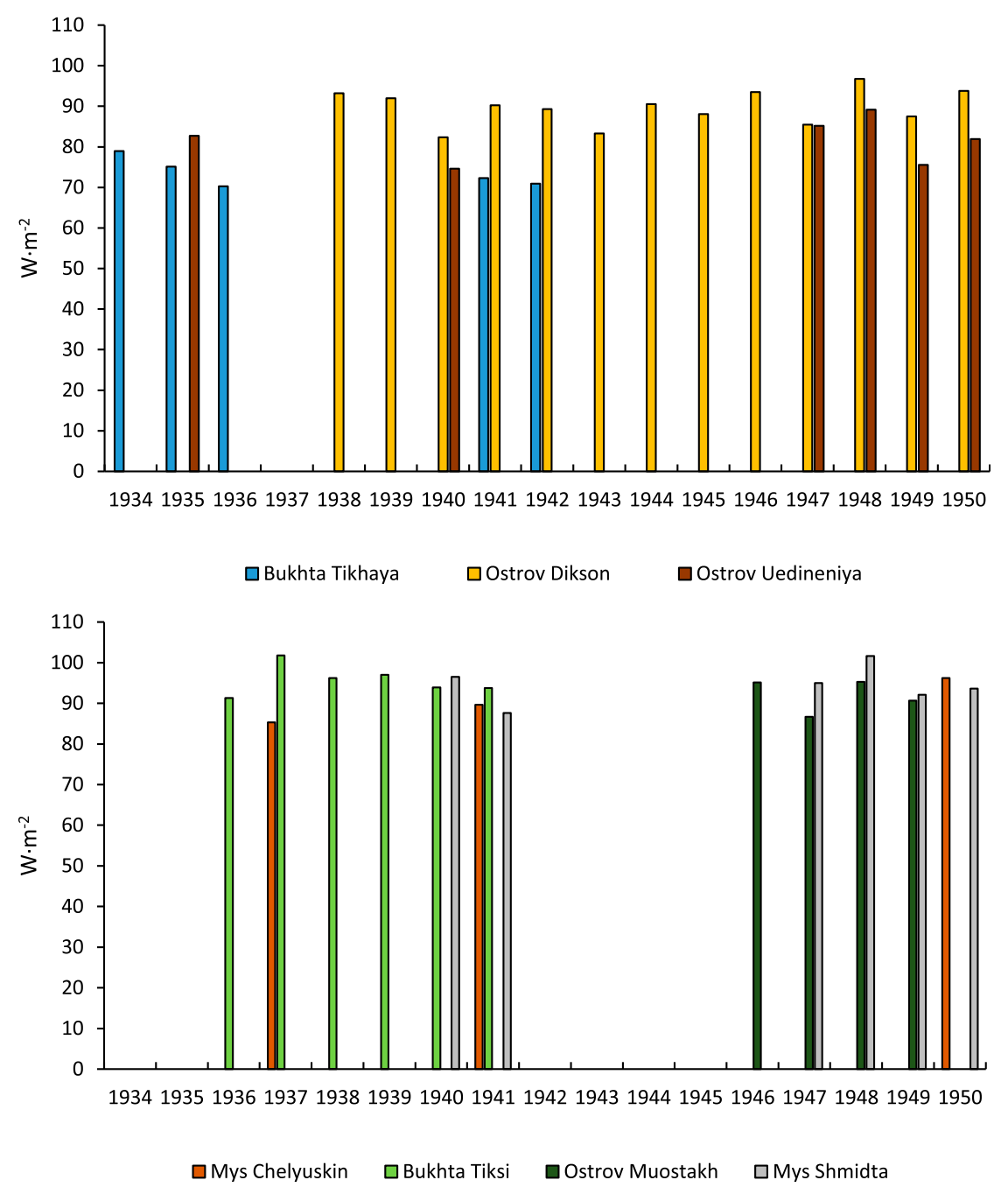

FIG. 6. Year-to-year courses of annual means of global solar radiation in the Russian Arctic during the ETCW.

intensification of anthropogenic pollution (Radionov et al. 2017) as well as a great rise in cloudiness (Chernokulsky and Esau 2019). As a result, in the Russian Arctic a great decrease of solar radiation is observed (see Fig. 3 in Radionov et al. 2017). In conclusion we can say that during the ETCW solar radiation increased, then stabilized, and then after 2000 decreased.

Chernokulsky and Esau (2019) found that total cloudiness in the Eurasian Arctic in the period 1936-2012 was highest in the 1940s and 2000s. This means that cloudiness in these times should influence the influx of solar radiation in a similar way. Thus, differences in values of global solar radiation and its components in the Russian Arctic calculated for both periods are probably driven mainly by the differences in aerosol concentration. This is possible, because Radionov et al. (2017) found that in the western part of the Russian Arctic there exists a statistically significant negative correlation between global radiation and AOD (not seen in the eastern part). In the two stations analyzed (Ostrov Dikson and Mys Chelyuskin) correlation coefficients reached -0.76 and -0.69 , respectively (see their Table 2).

As results from section 2, only for two stations (Ostrov Dikson and Mys Chelyuskin) located in Taymyr Peninsula (western Russian Arctic, see Fig. 1) do there exist very long series of solar radiation for both the ETCW and contemporary periods, in particular for Ostrov Dikson. For this reason, a reliable comparison of the character of solar radiation changes between the two mentioned periods can be made (see Figs. 7-9). Results presented in all of these figures evidently document that all kinds of solar radiation (direct, diffuse, and global) analyzed in the paper were greater during the ETCW (1937$50)$ than in the contemporary period (2001-19). Comparison of average solar conditions is only possible for Ostrov Dikson (Fig. 7), because for Mys Chelyuskin, as we mentioned earlier, only three years of data are available for the ETCW period, in which many gaps also exist. Of the two components of global radiation, diffuse radiation reveals on average a slightly greater decline from the ETCW to the contemporary period than does 

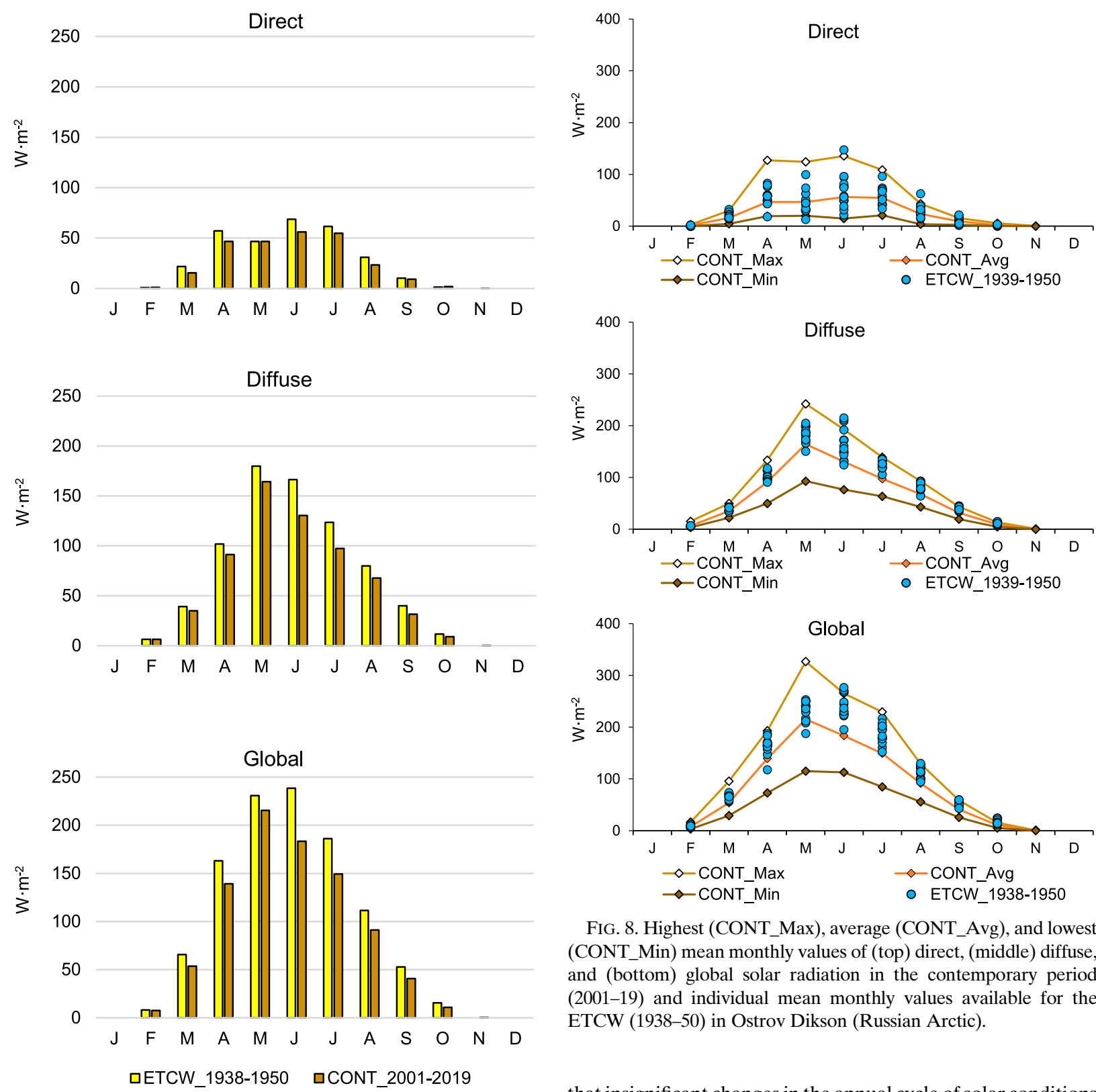

FIG. 7. Monthly average values of (top) direct, (middle) diffuse, and (bottom) global solar radiation during the ETCW (1938-50) and contemporary (2001-19) periods in Ostrov Dikson (Russian Arctic).

direct radiation. The annual average values are currently about $18 \%$ smaller than those for diffuse radiation (in absolute values, $6-7 \mathrm{~W} \cdot \mathrm{m}^{-2}$ smaller), while for direct radiation they are about $17 \%$ lower $\left(2-3 \mathrm{~W} \cdot \mathrm{m}^{-2}\right)$. The majority of summer months saw declines that were greater than the annual average, exceeding 20\% and even 30\% (August for direct radiation). The highest monthly averages of diffuse and global radiations occurred in May for both periods. On the other hand, the highest average direct solar radiation both during the ETCW and the present period were in June. Thus, we can conclude

FIG. 8. Highest (CONT_Max), average (CONT_Avg), and lowest (CONT_Min) mean monthly values of (top) direct, (middle) diffuse, and (bottom) global solar radiation in the contemporary period (2001-19) and individual mean monthly values available for the ETCW (1938-50) in Ostrov Dikson (Russian Arctic).

that insignificant changes in the annual cycle of solar conditions occurred between the two compared periods.

Figures 8 and 9 present individual monthly averages of solar radiation taken from all measurements done during the ETCW in Ostrov Dikson and Mys Chelyuskin, respectively, and compared with average values of the solar radiation calculated based on the data from the contemporary period. It is evident that, in Ostrov Dikson, the majority of monthly averages of both the global and diffuse radiation in the ETCW were higher than present average values (Fig. 8). It is worth adding that diffuse and global values of solar radiation in June were even higher than at present in as many as three years. The diffuse radiation was higher in the years 1944 (monthly average $=209$ $\left.\mathrm{W} \cdot \mathrm{m}^{-2}\right), 1946\left(212 \mathrm{~W} \cdot \mathrm{m}^{-2}\right)$, and $1948\left(215 \mathrm{~W} \cdot \mathrm{m}^{-2}\right)$, while the global radiation was higher in the years 1938 (monthly average $=$ $\left.268 \mathrm{~W} \cdot \mathrm{m}^{-2}\right), 1943\left(272 \mathrm{~W} \cdot \mathrm{m}^{-2}\right)$, and $1948\left(277 \mathrm{~W} \cdot \mathrm{m}^{-2}\right)$. By 
contrast, no monthly average in the ETCW was lower than the lowest value during the contemporary period. In the case of direct solar radiation, the dispersion of monthly averages taken from the ETCW is more or less symmetrical in relation to their average values for the contemporary period (Fig. 8). In some ETCW months the present range of direct solar radiation values was exceeded (both highest and lowest ones).

Significantly less reliable is the comparison of solar conditions between the two analyzed periods based on data available for Mys Chelyuskin (Fig. 9). Nevertheless, analysis of Fig. 9 generally confirms the results presented for Ostrov Dikson if the global radiation is taken into account. In most months, this type of radiation was higher or equal to contemporary average solar conditions. By contrast, opposite relations than in Ostrov Dikson are observed in Mys Chelyuskin when diffuse solar radiations is analyzed. All available monthly averages of the global radiation were lower in the ETCW than in the present (Fig. 9). On the other hand, the monthly values of direct solar radiation in Mys Chelyuskin were clearly higher during the ETCW in comparison to present times (except March and September). This pattern was significantly less visible in Ostrov Dikson (Fig. 8). In the latter station, however, as we noted earlier, a clearer pattern is observed in an analysis based on average values (see Fig. 7).

\section{Conclusions and final remarks}

The main results obtained from our investigations can be summarized as follows:

1) A literature search in libraries and archives for potential series of solar radiation measurements in the Arctic reveals 32 short-term series (observations made during expeditions) for before the mid-twentieth century (including 27 within the ETCW period) (Table 1, Fig. 1), covering large parts of the study area. Furthermore, the solar data are more or less evenly distributed across the study period. However, continuous actinometric observations began later (after the second IPY 1932/33) than short-term ones and were limited only to the Russian Arctic (see supplemental Table S2).

2) The analysis of available series of solar radiation data measured at actinometric stations in the second part of the ETCW reveals that, in the annual cycle, average monthly values of diffuse and global solar radiation were markedly largest in May and June, while those of direct radiation calculated at the horizontal surface were clearly largest either in June or in July (Figs. 2-4).

3) Diffuse solar radiation in the Russian Arctic was usually about 2 times the direct radiation on a horizontal plane in the ETCW-in all months and for the year as a whole (cf. Figs. 3, 2).

4) Yearly statistics on the global radiation clearly confirm that during the ETCW the eastern part of the Russian Arctic was sunnier than the western part, receiving $16-22 \mathrm{~W} \cdot \mathrm{m}^{-2}$ more energy. The spatial pattern of direct solar radiation is mainly responsible for the described features of global radiation in the Russian Arctic in the study period because diffuse solar radiation in this time had the opposite spatial
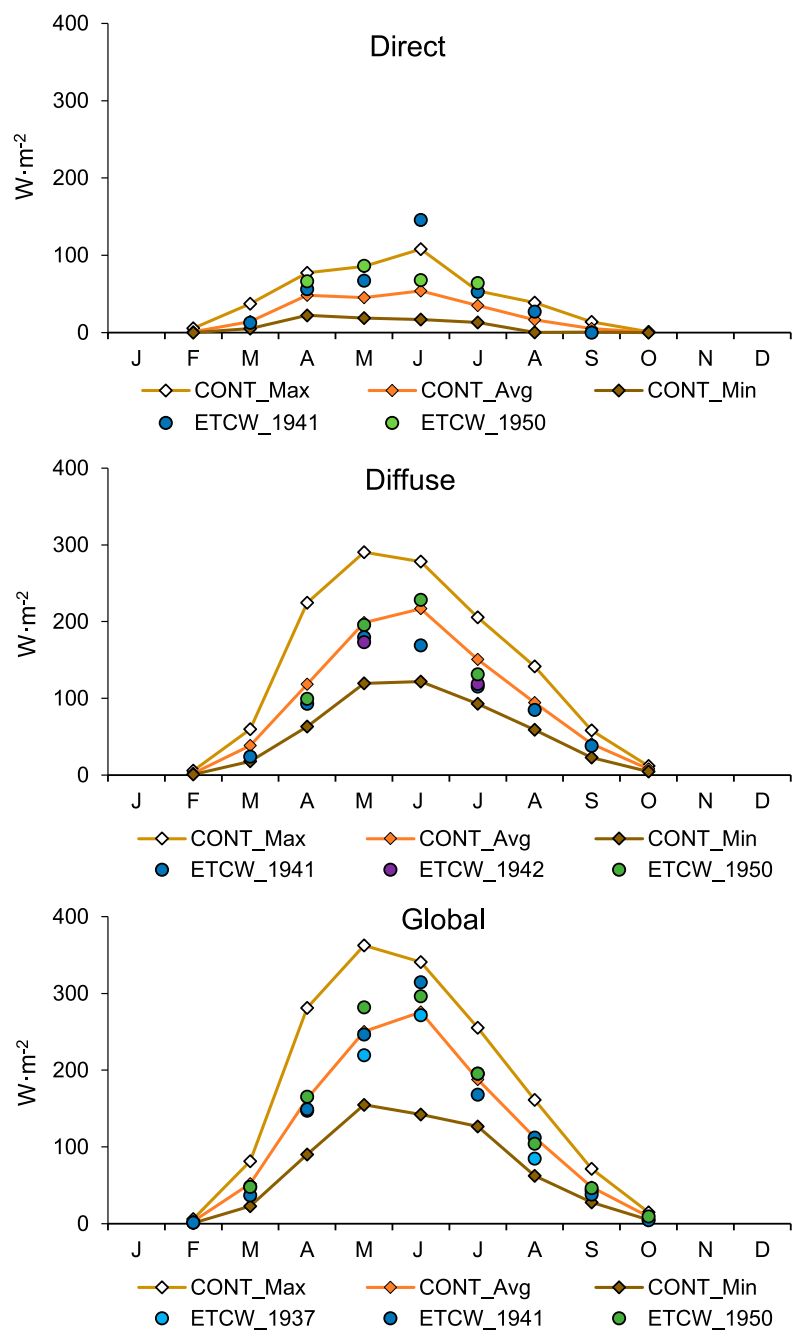

FIG. 9. Highest (CONT_Max), average (CONT_Avg), and lowest (CONT_Min) mean monthly values of direct, diffuse, and global solar radiation in the contemporary period (2001-19) and individual monthly means available for three years $(1937,1941$, and 1950) from the ECTW in Mys Chelyuskin (Russian Arctic).

pattern. This pattern was mainly caused by the larger amount of sulfate aerosol transported in the 1930s to the western part of the Russian Arctic than the eastern part. Solar elevation played a significantly less important role (stations in the east have lower latitudes than those in the west), except in the most northerly part of the study area.

5) No trends are evident in any kinds of long-term solar radiation series available for the period 1934-50 (Figs. 5, 6), but particularly in the one complete and thus most reliable series-that from Ostrov Dikson.

6) Annual average global solar radiation during the ETCW was slightly greater than in the period 1964-90 (by about $1-2 \mathrm{~W} \cdot \mathrm{m}^{-2}$ ), and markedly greater than in 2001-19 (by about $16 \mathrm{~W} \cdot \mathrm{m}^{-2}$; see Figs. 7-9). Both components of global solar radiation (direct and diffuse) also had clearly greater values during the ETCW than in the contemporary period. 
The stable solar conditions in the second half of the twentieth century in the Russian Arctic were noted despite the observed increase in anthropogenic pollution in this time. The reason for this was the low total cloudiness in 1970-90, particularly in spring but also in summer.

7) Nonsignificant changes in the annual cycle of solar conditions occurred between the ETCW and the contemporary period (Fig. 7).

8) Most individual monthly average values of global solar radiation available for the ETCW were higher than or equal to contemporary average solar conditions (Figs. 8, 9).

9) Our results reveal that in the Russian Arctic in the period 1920-2019 three phases of solar radiation changes can be distinguished: a brightening phase (1921-50), a stabilization phase (1951-93) and a dimming phase (after 2000). The lack of solar radiation measurements in the Russian Arctic for the period 1994-2000 does not allow for precise definition of the end of the stable phase or the onset of the dimming phase. This means that the pattern of solar radiation changes in the Arctic is different than that stated for the entire world (brightening-dimming-brightening). The greatest difference in trends (the opposite tendency) is noted in the modern period (2001-19), while there is full accordance in the ETCW period.

The paper presents the results of many years of preliminary surveying of library and archival materials concerning a less popular meteorological variable, that is, solar radiation. The search for this kind of data is very limited within the community engaged in data rescue. The important, but still not deeply explained role of solar radiation in the ETCW in the Arctic, being an effect of the lack of such data in world databases, motivated us to try to fill this knowledge gap. In recent years, we tried to collect all existing series of solar radiation measurements in the Arctic from before the mid-twentieth century, but mainly for the ETCW (1921-50). We are aware of the fact that we probably did not find all sources containing solar radiation data, but we are fairly sure that we reached the majority of them. The inventory of solar radiation series for the Arctic for before the mid-twentieth century can thus be considered a good start for further work. We hope that the international scientific community will join us in this effort and that, as a consequence, yet-undiscovered solar radiation measurements may also "see the light of day."

Acknowledgments. The study was carried out as a part of the scientific project titled "Causes of the early 20th century Arctic warming," funded by the National Science Centre, Poland (Grant 2015/19/B/ST10/02933), and the Research University-Initiative of Excellence: The Emerging Field "Global Environmental Changes," Climate Change Research Unit at Nicolaus Copernicus University in Torun. Doctors E. N. Rusina and V. F. Radionov are gratefully acknowledged for providing monthly totals of solar radiation data for Ostrov Dikson and Mys Chelyuskin for the period 2001-19. We also thank Professor Stephen Warren and one anonymous reviewer for constructive comments that significantly helped in improving our article. The study was designed by author
Przybylak. Data collection was done by Przybylak and authors Svyashchennikov and Wyszyński. Literature review was conducted by Przybylak, Svyashchennikov, and Wyszyński. Statistical analysis (including plots of figures) was done by author UsckaKowalkowska and Wyszyński. Interpretation of results was done by Przybylak, Uscka-Kowalkowska, and Svyashchennikov. Preparation of the paper was done by Przybylak with contributions from all coauthors. The authors declare that they have no conflicts of interest.

Data availability statement. Solar radiation data for the Russian Arctic for the periods 1934-50 and 2001-19 used in this paper are available from a public data repository (http:// dx.doi.org/10.18150/repod.0451825; Przybylak et al. 2020). Other data used in graphs are available from the corresponding author.

\section{REFERENCES}

Ångström, A., 1933: Part VII. On the total radiation from the sun and sky at Sveanor $\left(79^{\circ} 56.5^{\prime} \mathrm{N}, 18^{\circ} 18^{\prime} \mathrm{E}\right)$. Geogr. Ann., 15, 151160, https://doi.org/10.1080/20014422.1933.11880565.

Bengtsson, L., V. Semenov, and O. Johannessen, 2004: The early twentieth-century warming in the Arctic-A possible mechanism. J. Climate, 17, 4045-4057, https://doi.org/10.1175/15200442(2004)017<4045:TETWIT>2.0.CO;2.

Berezkin, V. A., 1929: Actinometric observations in the area of Wrangel Island in August 1929 (in Russian). Meteor. Vestn., 912, 233-245.

—_, 1937: Actinometric Manual for Polar Hydrometeorological Stations of Glavnogo Upravleniya Severnogo Morskogo Puti (in Russian). Izd. Glavsemorputi, 127 pp.

- 1938: Actinometric observations made for the area of Atlantic, Pacific and Indian Oceans during voyage of Krasin icebreaker and Svirstroy steamer from 23rd March 1934 to 21st March 1935 (in Russian). Tr. GGO, 22, 4-10.

Bessels, E., 1876: Physical Observations. Vol. 1, Scientific Results of the U.S. Arctic Expedition, Steamer Polaris, C.F. Hall Commanding, U.S. Government Printing Office, 986 pp., https://archive.org/details/cu31924029881095.

Brönnimann, S., and Coauthors, 2018: A roadmap to climate data rescue services. Geosci. Data J., 5, 28-39, https://doi.org/ $10.1002 /$ gdj3.56.

_ , and Coauthors, 2019: Unlocking pre-1850 instrumental meteorological records: A global inventory. Bull. Amer. Meteor. Soc., 100, ES389-ES413, https://doi.org/10.1175/BAMS-D-190040.1.

Chernigovskiy, N. T., 1946: Actinometric observations (in Russian). Aircraft Expedition "USSR-N-169", to the "Pole of Inaccessibility," Izd. Glavsevmorputi, 155-161.

_ 1948: Observations of global solar radiation in Wrangel Island (in Russian). Probl. Arkt., 2, 118-120.

- 1961a: Compendium of actinometry of the Soviet Arctic, 1931-1956 (in Russian). Tr. AANII, 233, 271.

- 1961b: Compendium of actinometry of the Soviet Arctic, 1931-1956 (in Russian). Tr. AANII, 233, 467.

Chernokulsky, A., and I. Esau, 2019: Cloud cover and cloud types in the Eurasian Arctic in 1936-2012. Int. J. Climatol., 39, 57715790, https://doi.org/10.1002/joc.6187.

Crowley, T. J., S. K. Baum, K.-Y. Kim, G. C. Hegerl, and W. T. Hyde, 2003: Modeling ocean heat content changes during the last millennium. Geophys. Res. Lett., 30, 1932, https://doi.org/ $10.1029 / 2003 \mathrm{gl017801.}$ 
Dissing, D., and G. Wendler, 1998: Solar radiation climatology of Alaska. Theor. Appl. Climatol., 61, 161-175, https://doi.org/ 10.1007/s007040050061.

Egorova, T., W. Schmutz, E. Rozanov, A. I. Shapiro, I. Usoskin, J. Beer, R. V. Tagirov, and T. Peter, 2018: Revised historical solar irradiance forcing. Astron. Astrophys., 615, A85, https:// doi.org/10.1051/0004-6361/201731199.

Eriksson, B. E., 1942: Studies in North-East Greenland 1939-1940: Part IV. Meteorological records and the ablation on the Fröya Glacier in relation to radiation and meteorological conditions. Geogr. Ann., 24, 23-50, https://doi.org/10.1080/ 20014422.1942.11880708.

Franklin, J., 1828: Narrative of a Second Expedition to the Polar Sea in the Years 1825, 1826 and 1827. John Murray, 320 pp.

Gavrilova, M. K., 1963: Radiation Climate of the Arctic (in Russian). Gidrometeoizdat, $225 \mathrm{pp}$.

Georgi, J., 1935: Die Eismittestation. Deutsche Grönland-Expedition A. Wegener 1929 und 1930-31. Wiss. Ergeb., 4, 191-386.

Götz, F. W. P., 1931: Zum Strahlungsklima des Spitzbergensommers: Strahlungs- und Ozonmessungen in der Köningsbucht 1929. Beitr. Geophys., 31, 119-154.

Grant, A., S. Brönnimann, T. Ewen, T. Griesser, and A. Stickler, 2009: The early twentieth century warm period in the European Arctic. Meteor. Z., 18, 425-432, https://doi.org/ 10.1127/0941-2948/2009/0391.

Hegerl, G. C., S. Brönnimann, A. Schurer, and T. Cowan, 2018: The early 20th century warming: Anomalies, causes, and consequences. Wiley Interdiscip. Rev.: Climate Change, 9, e522, https://doi.org/10.1002/WCC.522.

Kalitin, N. N., 1921: Radiation and polarimetric observations conducted in the town of Arkhangelsk and in the White Sea in the summer of 1920 (in Russian). Meteor. Vestn., 109-126.

_ 1924: Radiation, polarimetric and cloud observations conducted in August and September 1921 by the hydrographic expedition of the Arctic Ocean (in Russian). Zapiski po Gidrografii, 48, 153-193.

_- 1929: Some data on the incoming and outgoing of radiant energy for Matochkin Shar (in Russian). Izv. GGO, 4, 42-47.

Kekonen, T., 2006: Environmental information from the Svalbard ice core for the past 800 years. Acta Universitatis Ouluensis: Scientiae Rerum Naturalium, A469, 47 pp., http://jultika.oulu.fi/ files/isbn9514281853.pdf.

Kimball, H., 1931: Solar radiation intensities within the Arctic circle. Mon. Wea. Rev., 59, 154-156, https://doi.org/10.1175/ 1520-0493(1931)59<154:SRIWTA >2.0.CO;2.

Kopp, W., 1939: Diskussion der Ergebnisse der Oststation in Scoresbysund. Deutsche Grönland-Expedition A. Wegener 1929 und 1930-31. Wiss. Ergeb., 4 (2), 1-86.

Marshunova, M. S., and A. A. Mishin, 1994: Handbook of the radiation regime of the Arctic basin (results from the drift stations). University of Washington Applied Physics Laboratory Tech. Rep. APL-UW TR 9413, 52 pp.

— and N. T. Chernigovskiy, 1971: Radiation Regime in Foreign Arctic (in Russian). Gidrometeoizdat, 183 pp.

—, V. F. Radionov, and A. V. Tsvietkov, 1988: Long-term changes of aerosol optical depth of Arctic atmosphere (in Russian). Monitoring Klimata Arktiki, Gidrometeoizdat, 122-131.

Meteorological Services of Canada, 1940: Meteorology: Cape Hope's Advance Coppermine Chesterfield Inlet Meanook. Vol. I, Canadian Polar Year Expeditions 1932-33, Meteorological Services of Canada, $452 \mathrm{pp}$.

Mosby, H., 1932: Sunshine and Radiation. Vol. 1, The Norwegian North Polar Expedition with the "Maud" 1918-1925: Scientific Results, Geofysisk Institutt, 110 pp.
Ohmura, A., 1981: Climate and energy balance on Arctic tundra. Axel Heiberg Island, Canadian Arctic Archipelago, spring and summer 1969, 1970 and 1972. Doctoral thesis, Geographisches Institut, Eidgenössische Technische Hochschule Zürich, Zürcher Geographische Schriften 3, $448 \mathrm{pp}$.

, 1982: A historical review of studies on the energy balance of Arctic tundra. J. Climatol., 2, 185-195, https://doi.org/10.1002/ joc.3370020208.

, 2009: Observed decadal variations in surface solar radiation and their causes. J. Geophys. Res., 114, D00D05, https:// doi.org/10.1029/2008JD011290.

Olsson, H., 1936a: Sunshine and radiation, Mount Nordenskiöld, Spitsbergen. Geogr. Ann., 18, 93-118, https://doi.org/10.1080/ 20014422.1936.11880608.

_ 1936b: Scientific Results of the Norwegian-Swedish Spitzbergen Expedition in 1934: Part VIII. Radiation measurements on Isachsen's Plateau. Geogr. Ann., 18, 225-244, https://doi.org/ 10.1080/20014422.1936.11880613.

Piotrovitch, V. V., 1936: Short results of hydrophysical observations on board 1/k Krasin (in Russian). Sb. Nauchnye Rezultaty Ekspediciy na l/k "Krasin" w 1935 g., Izd. Glavsevmorputi, 103-105.

Przybylak, R., 2003: The Climate of the Arctic. Kluwer Academic, $270 \mathrm{pp}$.

, 2016: The Climate of the Arctic. 2nd ed. Springer, 287 pp.

_- P. Sviashchennikov, J. Uscka-Kowalkowska, and P. Wyszyński, 2020: Solar radiation data for the Russian Arctic for the periods 1934-1950 and 2001-2019. RepOD, accessed 10 April 2020, https://doi.org/10.18150/repod.0451825.

Radionov, V. F., Ed., 1997: Technological Handbook of the Climate of Russia (Arctic Region): Solar Radiation (in Russian). Gidrometeoizdat, 230 pp.

— - E. N. Rusina, and E. E. Sibir, 2017: Long-term variability of annual sums of total and absorbed solar radiation in the Arctic (in Russian). Probl. Arkt. Antarkt., 3, 39-50, https://doi.org/ 10.30758/0555-2648-2017-0-3-39-50.

Rosgidromet, 1997: Actinometric observations at stations (in Russian). Issue 5, Manual of Hydrometeorological Stations and Posts, Guidance Doc. GD 52.04.562-96, 146 pp.

Rusina, E. N., V. F. Radionov, and E. E. Sibir, 2013: Changes in aerosol and optical parameters of atmosphere in northern and southern polar regions after 2000 (in Russian). Probl. Arkt. Antarkt., 1, 51-60.

Ruthe, K., 1941: Die Grönland expedition der Universität Oxford, 1928. Polarforschung, 11 (1), 1-6.

Samoilenko, V. S., 1929: Actinometric observations in the Barents sea and Novaya Zemlya (in Russian). Tr. Morsk. Nauchn. Inst., 4, 39-43.

Samukova, E. A., E. V. Gorbarenko, and A. E. Erokhina, 2014: Long-term variations of solar radiation in Europe (in Russian). Meteor. Gidrol., 8, 15-24.

Shapiro, A. I., W. Schmutz, E. Rozanov, M. Schoell, M. Haberreiter, A. V. Shapiro, and S. Nyeki, 2011: A new approach to the longterm reconstruction of the solar irradiance leads to large historical solar forcing. Astron. Astrophys., 529, A67, https:// doi.org/10.1051/0004-6361/201016173.

Sokolik, I. N., 2008: Overview of radiation and Arctic aerosol interactions with LCLUC. Science Focus on High Latitudes in the Context of the International Polar Year, NASA LandCover/Land-Use Change Program Science Team Meeting, Adelphi, MD, University of Maryland, https://lcluc.umd.edu/ sites/default/files/lcluc_documents/sokolik_lcluc_may2008_ presentation_0.pdf. 
Stanhill, G., 1995: Solar irradiance, air pollution and temperature changes in the Arctic. Philos. Trans. Roy. Soc., A352, 247-258, https://doi.org/10.1098/rsta.1995.0068.

— , and O. Achiman, 2017: Early global radiation measurements: A review. Int. J. Climatol., 37, 1665-1671, https://doi.org/ 10.1002/joc. 4826 .

Sugden, J. C., and P. G. Mott, 1940: Oxford University Greenland expedition, 1938. Geogr. J., 95, 43-51, https://doi.org/10.2307/ 1788683.

Suo, L., O. H. Ottera, M. Bentsen, Y. Gao, and O. M. Johannessen, 2013: External forcing of the early 20th century Arctic warming. Tellus, 65A, 20578, https://doi.org/10.3402/tellusa.v65i0.20578.

Svyashchennikov, P. N., U. V. Prokhorova, and B. V. Ivanov, 2020: Comparison of atmospheric circulation in the area of Spitsbergen in 1920-1950 and in the modern warming period. Russ. Meteor. Hydrol., 45, 22-28, https://doi.org/10.3103/ S1068373920010033.

Treshnikov, A. F., Ed., 1985: Atlas Arktiki. Glavnoye Upravlenye Geodeziy i Kartografiy, 204 pp.
Wang, Y. M., J. L. Lean, and N. R. Sheeley Jr., 2005: Modeling the sun's magnetic field and irradiance since 1713. Astrophys. J., 625, 522-538, https://doi.org/10.1086/429689.

Wegener, K., 1939: Ergünzungen für Eismitte. Deutsche GrönlandExpedition Alfred Wegener 1929 und 1930-31. Wiss. Ergeb., 4 (2), 1-190.

Westman, J., 1903: Mesures de l'intensité de la radiation solaire faites en 1899 et en 1900 à la station d'hivernage suédoise à la baie de Treurenberg. Spitzberg. Miss. Scient. Pour la mesure d'un arc de méridien au Spitzberg enterprises en 1899-1902. Vol. II, Sec. VIII-e, B. Radiation Solaire, 59 pp.

Wild, M., 2012: Enlightening global dimming and brightening. Bull. Amer. Meteor. Soc., 93, 27-37, https://doi.org/10.1175/BAMSD-11-00074.1.

- A. Ohmura, C. Schär, G. Müller, D. Folini, M. Schwarz, M. Z. Hakuba, and A. Sanchez-Lorenzo, 2017: The Global Energy Balance Archive (GEBA) version 2017: A database for worldwide measured surface energy fluxes. Earth Syst. Sci. Data, 9, 601-613, https://doi.org/10.5194/essd-9-601-2017. 